\title{
Rational Synthesis of Contra-Thermodynamic Spiroacetals by Reductive Cyclizations
}

Leo R. Takaoka, Alexandre J. Buckmelter, Thomas E. La Cruz and Scott D. Rychnovsky* Department of Chemistry, 516, Rowland Hall, University of California-Irvine, Irvine, Ca 92697

Email address: srychnov@uci.edu

\section{Supporting information}

Table of Contents

General experimental

Preparation of Diols

Preparation of Orthoesters

Preparation of Cyano Acetals and Spiro acetals

NnOe Signals for Spiroacetals
Pages

2

$2-17$

$17-22$

22-39

40 


\section{General experimental:}

${ }^{1} \mathrm{H}$ NMR spectra were recorded at 400 or $500 \mathrm{MHz}$ on Bruker NMR spectrometers and were referenced to residual solvent peaks. ${ }^{13} \mathrm{C}$ NMR spectra were recorded at $125 \mathrm{MHz}$ on Bruker NMR spectrometers. Infrared spectra were recorded on a MIDAC Grams/Prospect FT-IR. All reagents were obtained commercially and purified prior to use. Tetrahydrofuran, diethyl ether, dichloromethane, and toluene were dried by filtration through alumina according to the methods described by Grubbs. Liquid chromatography was performed using forced flow of the indicated solvent system on reagent silica gel 60 . Thin layer chromatography (TLC) was performed on Whatman $250 \mathrm{~mm}$ layer silica gel plates. Optical purity of chiral diols were determined by GC, or by HPLC using a chiral column as noted in the "preparation" section of this document. Developed plates were visualized using p-anisaldehyde potassium permanganate, and UV light. All glassware was flame-dried and cooled under an inert atmosphere of argon unless otherwise stated. Moisture sensitive reactions were carried out under an inert atmosphere of argon using standard syringe/septa techniques.

\section{Preparation and characterization:}

\section{General procedure for the preparation of chloro-epoxides from alkene-ols:}

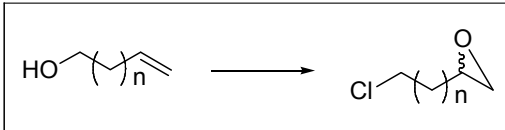

A solution of alcohol (1.0 equiv.) and 2,6-lutidine (1.5 equiv.) in DMF (1.0 M) was cooled to $0{ }^{\circ} \mathrm{C}$. $\mathrm{MsCl}(1.0$ equiv.) was added dropwise via syringe and the mixture was allowed to warm to ambient temperature and stirred for $1 \mathrm{hr}$. Anhydrous $\mathrm{LiCl}$ (1.5 equiv.) was added in one-portion and the yellow reaction mixture was allowed to stir. 
The reaction was quenched with brine and poured into a separating funnel containing $\mathrm{Et}_{2} \mathrm{O}$. The organic layer was separated and washed successively with brine and $\mathrm{H}_{2} \mathrm{O}$ ( $\times$ 5). The organic layer was dried over anhydrous $\mathrm{MgSO}_{4}$, filtered, and concentrated in vacuo. The crude residue was dissolved in $\mathrm{CH}_{2} \mathrm{Cl}_{2}(0.1 \mathrm{M})$ and cooled to $0{ }^{\circ} \mathrm{C}$. The reaction was fitted with an addition funnel and a solution of $m$ CPBA (1.5 equiv.) in $\mathrm{CH}_{2} \mathrm{Cl}_{2}(0.4 \mathrm{M})$ was added dropwise over a period of $30 \mathrm{~min}$. The reaction mixture was slowly warmed to ambient temperature and allowed to stir. The reaction was cooled to 0 ${ }^{\circ} \mathrm{C}$ and quenched over a period of $30 \mathrm{~min}$ by the dropwise addition of saturated aqueous $\mathrm{NaHCO}_{3}$. The organic layer was separated and washed successively with saturated aqueous $\mathrm{NaHCO}_{3}$ and brine. The organic layer was dried over anhydrous $\mathrm{Na}_{2} \mathrm{SO}_{4}$, filtered, and concentrated in vacuo. Purification by flash chromatography affords the title compound.

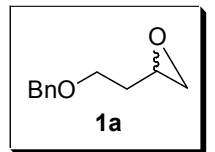

Epoxide 1a. Epoxide 1a was synthesized using a literature procedure: Schaus, S. E.; Brandes, B. D.; Larrow, J. F.; Tokunaga, M.; Hansen, K. B.; Gould, A. E.; Furrow, M. E.; Jacobsen, E. N. J. Am. Chem. Soc. 2002, 124, 1307-1315: ${ }^{1}$ H NMR (500 MHz, $\left.\mathrm{CDCl}_{3}\right) \delta$ 7.23-7.19 (m, $\left.5 \mathrm{H}\right), 4.54(\mathrm{~s}, 2 \mathrm{H}), 3.67-3.60(\mathrm{~m}, 2 \mathrm{H}), 3.11-3.07(\mathrm{~m}, 1 \mathrm{H}), 2.80$ $(\mathrm{t}, \mathrm{J}=4.3 \mathrm{~Hz}, 1 \mathrm{H}), 2.54(\mathrm{dd}, \mathrm{J}=5.0,2.8 \mathrm{~Hz}, 1 \mathrm{H}), 1.96-1.90(\mathrm{~m}, 1 \mathrm{H}), 1.82-1.75(\mathrm{~m}, 1$ $\mathrm{H}) ;{ }^{13} \mathrm{C}$ NMR $\left(125 \mathrm{MHz}, \mathrm{CDCl}_{3}\right) \delta 138.2,128.4,127.6,73.1,67.0,50.1,47.1,32.9$; HRMS (EI/isobutane) $m / z$ calcd for $\mathrm{C}_{11} \mathrm{H}_{13} \mathrm{O}_{2}[\mathrm{M}-\mathrm{H}]^{+}$177.0916, found 177.0917.

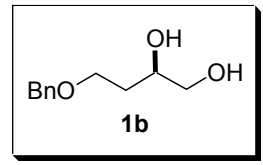


Diol 1b. Diol 1b was synthesized using a literature procedure: Schaus, S. E.; Brandes, B. D.; Larrow, J. F.; Tokunaga, M.; Hansen, K. B.; Gould, A. E.; Furrow, M. E.; Jacobsen, E. N. J. Am. Chem. Soc. 2002, 124, 1307-1315: ${ }^{1} \mathrm{H}$ NMR (500 MHz, $\left.\mathrm{CDCl}_{3}\right) \delta$ 7.36-7.28 (m, $5 \mathrm{H}), 4.52(\mathrm{~s}, 2 \mathrm{H}), 4.11-4.01(\mathrm{~m}, 2 \mathrm{H}), 3.74-3.49(\mathrm{~m}, 3 \mathrm{H}), 1.94-1.88(\mathrm{~m}, 1 \mathrm{H})$, 1.82-1.75 (m, $1 \mathrm{H}) ;{ }^{13} \mathrm{C}$ NMR (125 MHz, $\left.\mathrm{CDCl}_{3}\right) \delta$ 137.8, 128.4, 127.7, 127.6, 73.5, 68.9, 68.3, 67.0, 32.9; IR (neat) 3459, 2864, $1101 \mathrm{~cm}^{-1}$; HRMS (EI/isobutane) $\mathrm{m} / \mathrm{z}$ calcd for $\mathrm{C}_{11} \mathrm{H}_{15} \mathrm{O}_{3}[\mathrm{M}-\mathrm{H}]^{+}$195.1020, found 195.1022.

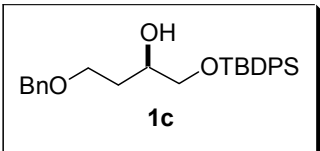

Alcohol 1c. Alcohol 1c was synthesized using a literature procedure: Schaus, S. E.; Brandes, B. D.; Larrow, J. F.; Tokunaga, M.; Hansen, K. B.; Gould, A. E.; Furrow, M. E.; Jacobsen, E. N. J. Am. Chem. Soc. 2002, 124, 1307-1315.: ${ }^{1} \mathrm{H}$ NMR $(500 \mathrm{MHz}$, $\left.\mathrm{CDCl}_{3}\right) \delta 7.98-7.28(\mathrm{~m}, 15 \mathrm{H}), 4.40(\mathrm{~s}, 2 \mathrm{H}), 4.27-4.23(\mathrm{~m}, 2 \mathrm{H}), 3.87-3.83(\mathrm{~m}, 1 \mathrm{H})$, 3.60-2.46 (m, $3 \mathrm{H}), 1.92-1.90(\mathrm{~m}, 2 \mathrm{H}), 1.55$ (br s, $1 \mathrm{H}), 1.03$ (s, $9 \mathrm{H}) ;{ }^{13} \mathrm{C}$ NMR (125 $\left.\mathrm{MHz}, \mathrm{CDCl}_{3}\right) \delta 138.3,135.9,135.7,134.8,129.8,129.6,129.4,128.3,127.6,127.5$, 73.3, 72.9, 69.1, 66.2, 34.5, 26.9, 19.4; IR (neat) 3449, 2929, 2857, $1112 \mathrm{~cm}^{-1} ;[\alpha]_{\mathrm{D}}+25.9$ (c $0.81 \mathrm{EtOH})$. Enantiomeric excess was determined by HPLC with a Chiralcel OD-H column (10\% iPrOH/hexanes, $1 \mathrm{~mL} / \mathrm{min}, 254 \mathrm{~nm}) ;(R)$ enantiomer $\mathrm{t}_{\mathrm{r}}=5.13 \mathrm{~min}$ (major); $(S)$ enantiomer $\mathrm{t}_{\mathrm{r}}=15.64 \min ($ minor); $67 \%$ ee

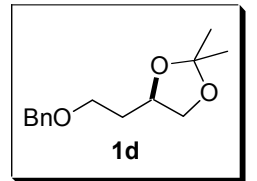

Acetonide 1d. A $100 \mathrm{~mL}$ round bottom flask was added a solution of diol $\mathbf{1 b}(1.760 \mathrm{~g}$, $8.97 \mathrm{mmol})$ in freshly distilled acetone $(40.0 \mathrm{~mL}, 0.2 \mathrm{M}) .2$ 2,2-DMP $(15.0 \mathrm{~mL})$ was added 
via syringe followed by a catalytic amount of $p$ TSA $(0.465 \mathrm{~g}, 2.44 \mathrm{mmol})$. The reaction mixture was warmed to $58{ }^{\circ} \mathrm{C}$ and allowed to stir for $3 \mathrm{~d}$. The reaction was cooled to ambient temperature and quenched by the dropwise addition of TEA $(2 \mathrm{~mL})$. The mixture was diluted with $\mathrm{Et}_{2} \mathrm{O}(150 \mathrm{~mL})$ and washed successively with saturated aqueous $\mathrm{NaHCO}_{3}(100 \mathrm{~mL})$ and $\mathrm{H}_{2} \mathrm{O}(100 \mathrm{~mL})$. The organic layer was dried over anhydrous $\mathrm{MgSO}_{4}$, filtered, and concentrated in vacuo. Purification by flash chromatography (10\% $\mathrm{Et}_{2} \mathrm{O} /$ hexanes) on silica gel previously deactivated with $4 \%$ TEA/hexanes affords $\mathbf{1 d}$ as an orange oil (1.927 g, 91\%): ${ }^{1} \mathrm{H}$ NMR (500 MHz, $\left.\mathrm{CDCl}_{3}\right) \delta$ 7.35-7.27 (m, $\left.5 \mathrm{H}\right), 4.50$ (s, $2 \mathrm{H}), 4.22$ (quint, $\mathbf{J}=6.1 \mathrm{~Hz}, 1 \mathrm{H}), 4.60(\mathrm{dd}, \mathrm{J}=8.1,6.0 \mathrm{~Hz}, 1 \mathrm{H}), 3.61-3.54(\mathrm{~m}, 3 \mathrm{H})$, 1.96-1.82 (m, $2 \mathrm{H}), 1.40(\mathrm{~s}, 3 \mathrm{H}), 1.36(\mathrm{~s}, 3 \mathrm{H}) ;{ }^{13} \mathrm{C}$ NMR (125 MHz, $\left.\mathrm{CDCl}_{3}\right) \delta 138.3$, $128.4,127.7,127.6,108.5,73.9,73.1,69.6,67.0,33.8,26.9,25.8 ;$ IR (neat) 2863, 1096 $\mathrm{cm}^{-1}$; HRMS (EI/isobutane) $\mathrm{m} / z$ calcd for $\mathrm{C}_{13} \mathrm{H}_{17} \mathrm{O}_{3}\left[\mathrm{M}-\mathrm{CH}_{3}\right]^{+}$121.1178, found 121.1173.

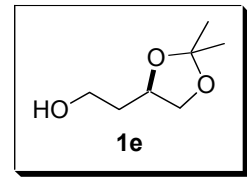

Alcohol 1e. A $25 \mathrm{~mL}$ 3-neck round bottom flask equipped with a glass stir bar and dry ice condenser was added a suspension of freshly cut pieces of lithium wire $(0.225 \mathrm{~g}$, $32.51 \mathrm{mmol})$ in THF $(3.0 \mathrm{~mL})$ and cooled to $-78{ }^{\circ} \mathrm{C}$. Anhydrous $\mathrm{NH}_{3}(7.0 \mathrm{~mL})$ was allowed to condense into the flask and the blue mixture was allowed to stir for $15 \mathrm{~min}$. A solution of acetonide $1 \mathbf{d}(0.048 \mathrm{~g}, 0.20 \mathrm{mmol})$ in THF $(3.0 \mathrm{~mL})$ was added dropwise via syringe and the reaction mixture was allowed to stir for $5 \mathrm{~min}$. The reaction was slowly warmed to $0{ }^{\circ} \mathrm{C}$ to evaporate most of the $\mathrm{NH}_{3}$ and quenched by the dropwise addition of saturated aqueous $\mathrm{NH}_{4} \mathrm{Cl}(3 \mathrm{~mL})$. The mixture was warmed to ambient temperature and 
diluted with $\mathrm{Et}_{2} \mathrm{O}(30 \mathrm{~mL})$. The organic layer was washed with brine $(10 \mathrm{~mL})$, dried over anhydrous $\mathrm{MgSO}_{4}$, filtered, and concentrated in vacuo. Purification by flash chromatography (50\% EtOAc/hexanes) on silica gel affords 1e as a light yellow oil (0.028 g, 94\%): ${ }^{1} \mathrm{H}$ NMR (500 MHz, $\left.\mathrm{CDCl}_{3}\right) \delta 4.26$ (quint, $\left.\mathrm{J}=5.9 \mathrm{~Hz}, 1 \mathrm{H}\right), 4.11-4.03$ (m, $2 \mathrm{H}), 3.78$ (tt, J = 5.9, $2.1 \mathrm{~Hz}, 2 \mathrm{H}), 2.40$ (br s, $1 \mathrm{H}), 1.81-1.79$ (m, $2 \mathrm{H}), 1.38$ (s, 3 H), 1.34 (s, $3 \mathrm{H}) ;{ }^{13} \mathrm{C}$ NMR (125 MHz, $\left.\mathrm{CDCl}_{3}\right) \delta$ 109.0, 75.1, 69.4, 60.5, 35.6, 26.8, 25.6; IR (neat) $3400,2937,1059 \mathrm{~cm}^{-1}$; HRMS (EI/isobutane) $\mathrm{m} / z$ calcd for $\mathrm{C}_{6} \mathrm{H}_{11} \mathrm{O}_{3}\left[\mathrm{M}-\mathrm{CH}_{3}\right]^{+}$ 131.0708, found 131.0707.

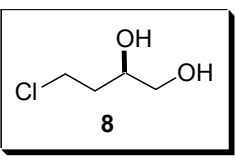

Diol 8. A $25 \mathrm{~mL}$ round bottom flask was added a solution of alcohol 1e $(0.234 \mathrm{~g}, 1.60$ mmol) and 2,6-lutidine $(0.80 \mathrm{~mL}, 6.80 \mathrm{mmol})$ in $\operatorname{DMF}(5.0 \mathrm{~mL}, 0.3 \mathrm{M})$ and cooled to 0 ${ }^{\circ} \mathrm{C} . \mathrm{MsCl}(0.13 \mathrm{~mL}, 1.64 \mathrm{mmol})$ was added dropwise via syringe and the mixture was allowed to warm to ambient temperature and stirred for $1 \mathrm{~h}$. Anhydrous $\mathrm{LiCl}(0.091 \mathrm{~g}$, $2.15 \mathrm{mmol}$ ) was added in one-portion and the yellow reaction mixture was allowed to stir for $24 \mathrm{~h}$. The reaction was quenched with brine $(2.0 \mathrm{~mL})$ and poured into a separating funnel containing $\mathrm{Et}_{2} \mathrm{O}(60 \mathrm{~mL})$. The organic layer was separated and washed successively with cold $\left(0{ }^{\circ} \mathrm{C}\right) 1.0 \mathrm{M}$ aqueous $\mathrm{NaHSO}_{4}(10 \mathrm{~mL} \times 2)$, saturated aqueous $\mathrm{NaHCO}_{3}(10 \mathrm{~mL})$, brine $(10 \mathrm{~mL})$, and $\mathrm{H}_{2} \mathrm{O}(10 \mathrm{~mL} \times 5)$. The organic layer was dried over anhydrous $\mathrm{MgSO}_{4}$, filtered, and concentrated in vacuo. The crude residue was dissolved in $\mathrm{MeOH}(6.0 \mathrm{~mL}, 0.3 \mathrm{M})$ and Dowex ${ }^{\circledR} 50 \mathrm{X} 8-100$ acidic resin $(0.265 \mathrm{~g})$ was added in one-portion and the suspension was allowed to vigorously stir for $14 \mathrm{~h}$. The mixture was filtered and the solvent was removed in vacuo. Purification by flash 
chromatography (50\% EtOAc/hexanes) on silica gel affords diol 8 as a colorless oil (0.112 g, 56\% over two steps): ${ }^{1} \mathrm{H}$ NMR $\left(500 \mathrm{MHz}, \mathrm{CDCl}_{3}\right) \delta$ 3.99-3.93 (m, $\left.1 \mathrm{H}\right), 3.76-$

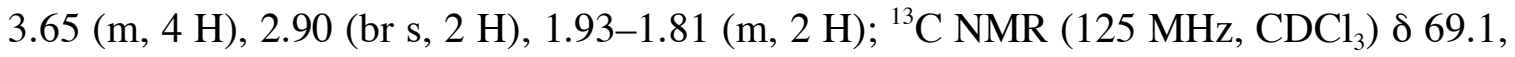
66.5, 41.5, 35.5; IR (neat) 3366, 2929, $1091 \mathrm{~cm}^{-1}$.

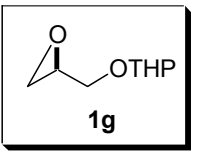

Epoxide 1g. Epoxide 1g was synthesized using a literature procedure: Jung, M. E.; Shishido, K.; Davis, L. H. J. Org. Chem. 1982, 47, 891-892: ${ }^{1} \mathrm{H}$ NMR (500 MHz, $\mathrm{CDCl}_{3}$ ) $\delta 4.65(\mathrm{t}, \mathrm{J}=3.7 \mathrm{~Hz}, 0.5 \mathrm{H}), 4.63(\mathrm{t}, \mathrm{J}=3.5 \mathrm{~Hz}, 0.5 \mathrm{H}), 3.93(\mathrm{dd}, \mathrm{J}=11.7,3.2 \mathrm{~Hz}, 0.5 \mathrm{H})$, 3.87-3.82 (m, $1 \mathrm{H}), 3.69(\mathrm{dq}, \mathrm{J}=11.8,5.1 \mathrm{~Hz}, 1 \mathrm{H}), 3.52-3.48(\mathrm{~m}, 1 \mathrm{H}), 3.38(\mathrm{dd}, \mathrm{J}=$ 11.7, $6.4 \mathrm{~Hz}, 0.5 \mathrm{H}), 3.19-3.15(\mathrm{~m}, 1 \mathrm{H}), 2.80-2.78(\mathrm{~m}, 1 \mathrm{H}), 2.67$ (dd, J = 5.2, $2.7 \mathrm{~Hz}$, $0.5 \mathrm{H}), 2.58(\mathrm{dd}, \mathrm{J}=5.0,2.7 \mathrm{~Hz}, 0.5 \mathrm{H}), 1.83-1.79(\mathrm{~m}, 1 \mathrm{H}), 1.75-1.67(\mathrm{~m}, 1 \mathrm{H}), 1.60-$ 1.49 (m, $4 \mathrm{H}) ;{ }^{13} \mathrm{C}$ NMR (125 MHz, $\left.\mathrm{CDCl}_{3}\right) \delta$ 98.9, 98.7, 68.4, 67.2, 62.2, 62.0, 50.9, 50.5, 44.5 (2), 30.4, 30.3, 25.3 (2), 19.3, 19.1; IR (neat) 2943, $1034 \mathrm{~cm}^{-1}$; HRMS (EI/isobutane) $m / z$ calcd for $\mathrm{C}_{8} \mathrm{H}_{13} \mathrm{O}_{3}[\mathrm{M}-\mathrm{H}]^{+}$157.0864, found 157.0863.

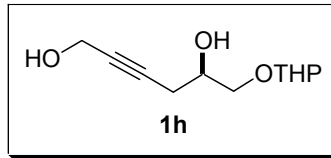

Diol 1h. A $25 \mathrm{~mL}$ round bottom flask was added a solution of 2-propyn-1-ol $(0.10 \mathrm{~mL}$, $1.64 \mathrm{mmol})$ in $\mathrm{Et}_{2} \mathrm{O}(3.3 \mathrm{~mL}, 0.5 \mathrm{M})$ and cooled to $-78^{\circ} \mathrm{C}$. A solution of $t \mathrm{BuLi}(3.6 \mathrm{~mL}$, 1.2 $\mathrm{M}$ in pentane, $4.42 \mathrm{mmol}$ ) was added slowly down the side of the flask over a period of $15 \mathrm{~min}$. The mixture was allowed to stir at $-78{ }^{\circ} \mathrm{C}$ for another $10 \mathrm{~min}$. $\mathrm{CuCN}(0.078$ $\mathrm{g}, 0.87 \mathrm{mmol}$ ) was added in one-portion followed by the dropwise addition of a solution of epoxide $1 \mathrm{~g}(0.103 \mathrm{~g}, 0.65 \mathrm{mmol})$ in $\mathrm{Et}_{2} \mathrm{O}(0.5 \mathrm{~mL}, 0.4 \mathrm{M})$. The reaction mixture was 
covered in foil and vigorously stirred while slowly warming to ambient temperature over a period of $20 \mathrm{~h}$ in the dark. The reaction was quenched by the dropwise addition of saturated aqueous $\mathrm{NaKC}_{4} \mathrm{H}_{4} \mathrm{O}_{6}(2 \mathrm{~mL})$. Saturated aqueous $\mathrm{NH}_{4} \mathrm{Cl}(2 \mathrm{~mL})$ was added and the mixture was vigorously stirred for $15 \mathrm{~min}$. The mixture was poured into a separating funnel and extracted with $\mathrm{Et}_{2} \mathrm{O}(10 \mathrm{~mL} \times 3)$. The combined organic layers were washed with brine $(20 \mathrm{~mL})$, dried over anhydrous $\mathrm{MgSO}_{4}$, filtered, and concentrated in vacuo. Purification by flash chromatography (100\% EtOAc) on silica gel affords $\mathbf{1 h}$ (colorless oil) as a mixture of diastereomers $(0.093 \mathrm{~g}, 69 \%):{ }^{1} \mathrm{H} \mathrm{NMR}\left(500 \mathrm{MHz}, \mathrm{CDCl}_{3}\right) \delta 4.58-$ 4.55 (m, $1 \mathrm{H}), 4.24-4.21(\mathrm{~m}, 2 \mathrm{H}), 3.91-3.70(\mathrm{~m}, 3 \mathrm{H}), 3.66-3.51$ (m, $2 \mathrm{H}), 2.61$ (br s, 2 H), 2.49-2.44 (m, $2 \mathrm{H}), 1.77-1.70$ (m, $2 \mathrm{H}), 1.62-1.52$ (m, $4 \mathrm{H}) ;{ }^{13} \mathrm{C}$ NMR (125 MHz, $\left.\mathrm{CDCl}_{3}\right) \delta 100.4,100.2,97.0,96.8,82.2,81.9,72.5$ (2), 71.6, 71.5, 69.1 (2), 62.1, 62.0, 30.7, 30.6, 25.3 (2), 23.8, 23.7, 19.0 (2); IR (neat) 3392, 2943, $1024 \mathrm{~cm}^{-1}$; HRMS (EI/isobutane) $\mathrm{m} / z$ calcd for $\mathrm{C}_{11} \mathrm{H}_{17} \mathrm{O}_{4}[\mathrm{M}-\mathrm{H}]^{+}$213.1126, found 213.1125 .

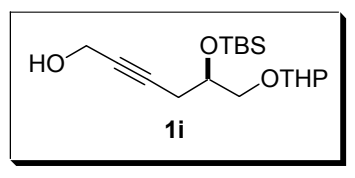

Alcohol 1i. A $25 \mathrm{~mL}$ round bottom flask was added a solution of diol $\mathbf{1 h}(0.418 \mathrm{~g}, 1.95$ mmol $)$ in $\mathrm{CH}_{2} \mathrm{Cl}_{2}(4.30 \mathrm{~mL}, 0.5 \mathrm{M})$. 2,6-lutidine $(1.10 \mathrm{~mL}, 9.75 \mathrm{mmol})$ was added via syringe and the mixture was cooled to $-78{ }^{\circ} \mathrm{C}$. TBSOTf $(1.30 \mathrm{~mL}, 5.85 \mathrm{mmol})$ was added dropwise and the reaction mixture was allowed to stir at $-78{ }^{\circ} \mathrm{C}$ for $4 \mathrm{~h}$. The reaction was slowly warmed to $0{ }^{\circ} \mathrm{C}$ over a period of $30 \mathrm{~min}$ and quenched with saturated aqueous $\mathrm{NH}_{4} \mathrm{Cl}(3 \mathrm{~mL})$. The mixture was warmed to ambient temperature and extracted with $\mathrm{CH}_{2} \mathrm{Cl}_{2}(30 \mathrm{~mL} \times 2)$. The combined organic layers were washed successively with cold $\left(0{ }^{\circ} \mathrm{C}\right) 1.0 \mathrm{M}$ aqueous $\mathrm{NaHSO}_{4}(30 \mathrm{~mL} \times 2)$, saturated aqueous $\mathrm{NaHCO}_{3}(50 \mathrm{~mL})$, 
and brine $(50 \mathrm{~mL})$. The organic layer was dried over anhydrous $\mathrm{Na}_{2} \mathrm{SO}_{4}$, filtered, and concentrated in vacuo. The crude residue was dissolved in wet hexanes $(195.0 \mathrm{~mL}, 0.01$ M) and neutral $\mathrm{Al}_{2} \mathrm{O}_{3}$ (42.776 g) was added in one-portion and the suspension was allowed to vigorously stir for $1 \mathrm{~h}$. The mixture was filtered, rinsed with EtOAc (500 $\mathrm{mL}$ ), and concentrated in vacuo. Purification by flash chromatography (20\% EtOAc/hexanes) on silica gel affords alcohol 1i as a colorless oil ( $0.553 \mathrm{~g}, 86 \%$ over two steps): ${ }^{1} \mathrm{H}$ NMR (500 MHz, $\mathrm{CDCl}_{3}$ ) $\delta$ 4.63-4.60 (m, $\left.1 \mathrm{H}\right), 4.23-4.22$ (m, $\left.2 \mathrm{H}\right), 3.97-3.94$ (m, 0.5 H), 3.68-3.82 (m, $1 \mathrm{H}), 3.78-3.75(\mathrm{~m}, 0.5 \mathrm{H}), 3.70-3.65$ (m, $0.5 \mathrm{H}), 3.60-3.57$ (m, 0.5 H), 3.52-3.46 (m, $1 \mathrm{H}), 3.42-3.40(\mathrm{~m}, 0.5 \mathrm{H}), 3.24-3.30$ (m, $0.5 \mathrm{H}), 2.48-2.38$ (m, $2 \mathrm{H}), 1.76-1.70(\mathrm{~m}, 2 \mathrm{H}), 1.62-1.51(\mathrm{~m}, 4 \mathrm{H}), 0.89(\mathrm{~s}, 9 \mathrm{H}), 0.11-0.07(\mathrm{~m}, 6 \mathrm{H}) ;{ }^{13} \mathrm{C}$ NMR (125 MHz, $\left.\mathrm{CDCl}_{3}\right) \delta 99.0$ (2), 96.7, 96.6, 80.0, 79.9, 71.4, 71.0, 70.4 (2), 62.0, $61.9,30.5,30.3,25.8,25.4$ (2), 25.2, 25.0, 19.3, 19.2, 18.1, -4.5, -4.6; IR (neat) 3435, 2930, 1121, $1035 \mathrm{~cm}^{-1}$; HRMS (EI/isobutane) $\mathrm{m} / z$ calcd for $\mathrm{C}_{13} \mathrm{H}_{23} \mathrm{O}_{4} \mathrm{Si}[\mathrm{M}-t \mathrm{Bu}]^{+}$ 271.1366, found 271.1354 .

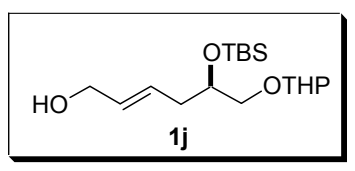

Alcohol 1j. A $50 \mathrm{~mL}$ round bottom flask was added a solution of $\mathbf{1 i}(0.442 \mathrm{~g}, 1.34$ mmol) in $\mathrm{Et}_{2} \mathrm{O}(19.1 \mathrm{~mL}, 0.07 \mathrm{M})$ and cooled to $0{ }^{\circ} \mathrm{C}$. $\operatorname{RedAl}^{\circledR}(0.52 \mathrm{~mL}, 65 \%$ in $\mathrm{PhMe}$, $2.68 \mathrm{mmol}$ ) was added dropwise via syringe with the evolution of $\mathrm{H}_{2}$ gas. The reaction mixture was warmed to ambient temperature and allowed to stir for $19 \mathrm{~h}$. The mixture was cooled to $0{ }^{\circ} \mathrm{C}$ and quenched by the dropwise addition of $\mathrm{HCO}_{3} \mathrm{CH}_{3}(1 \mathrm{~mL})$. The mixture was warmed to ambient temperature and saturated aqueous $\mathrm{NH}_{4} \mathrm{Cl}(5 \mathrm{~mL})$ was added followed by saturated aqueous $\mathrm{NaKC}_{4} \mathrm{H}_{4} \mathrm{O}_{6}(10 \mathrm{~mL})$. The mixture was vigorously 
stirred until phase separation was complete $(c a .2 \mathrm{~h})$. The mixture was poured into a separating funnel containing $\mathrm{Et}_{2} \mathrm{O}(150 \mathrm{~mL})$ and washed successively with saturated aqueous $\mathrm{NaHSO}_{4}(100 \mathrm{~mL})$, saturated aqueous $\mathrm{NaHCO}_{3}(100 \mathrm{~mL})$, and brine $(100 \mathrm{~mL})$. The organic layer was dried over anhydrous $\mathrm{MgSO}_{4}$, filtered, and concentrated in vacuo. Purification by flash chromatography (20\% EtOAc/hexanes) on silica gel affords $\mathbf{1 j}$ (colorless oil) as a mixture of diastereomers $(0.299 \mathrm{~g}, 68 \%)$ : ${ }^{1} \mathrm{H}$ NMR $\left(500 \mathrm{MHz}, \mathrm{CDCl}_{3}\right)$

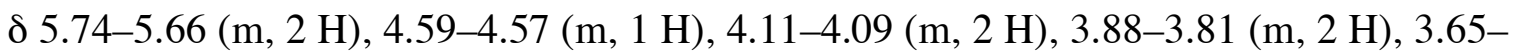
$3.62(\mathrm{~m}, 1 \mathrm{H}), 3.51-3.48(\mathrm{~m}, 1 \mathrm{H}), 3.29-3.24(\mathrm{~m}, 1 \mathrm{H}), 2.34-2.32(\mathrm{~m}, 1 \mathrm{H}), 2.24-2.17$ (m, $1 \mathrm{H}), 2.14-2.17(\mathrm{~m}, 1 \mathrm{H}), 1.84-1.77(\mathrm{~m}, 1 \mathrm{H}), 1.61-1.47(\mathrm{~m}, 4 \mathrm{H}), 0.88(\mathrm{~s}, 9 \mathrm{H})$, 0.08-0.05 (m, $6 \mathrm{H}) ;{ }^{13} \mathrm{C}$ NMR (125 MHz, $\mathrm{CDCl}_{3}$ ) $\delta 131.5$ (2), 129.1, 129.0, 99.1, 99.0, $71.5,71.3,71.2(2), 63.8,63.7,62.0,61.9,37.9,37.8,30.6,30.5,25.8,25.4(2), 19.4$, 19.3, 18.2 (2), -4.4 (2), -4.5, -4.7; IR (neat) 3447, 2929, 1123, $1035 \mathrm{~cm}^{-1}$; HRMS (EI/isobutane) $\mathrm{m} / z$ calcd for $\mathrm{C}_{17} \mathrm{H}_{34} \mathrm{O}_{4} \mathrm{Si}[\mathrm{M}]^{+} 330.2226$, found 330.2233 .

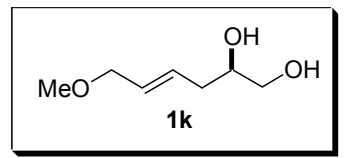

Diol 1k. A $25 \mathrm{~mL}$ round bottom flask was added a suspension of $\mathrm{NaH}(0.134 \mathrm{~g}, 60 \%$ in oil, $3.35 \mathrm{mmol})$ in THF $(2.3 \mathrm{~mL}, 0.5 \mathrm{M})$ and cooled to $0{ }^{\circ} \mathrm{C}$. A solution of alcohol $\mathbf{1 j}$ (0.397 $\mathrm{g}, 1.19 \mathrm{mmol})$ in THF $(0.5 \mathrm{~mL})$ was added dropwise via syringe with the evolution of $\mathrm{H}_{2}$ gas. The mixture is warmed to ambient temperature and allowed to stir for $30 \mathrm{~min}$. MeI $(0.37 \mathrm{~mL}, 5.95 \mathrm{mmol})$ was added dropwise via syringe and the flask was covered in foil and allowed to stir for $9 \mathrm{~h}$ in the dark. The mixture was cooled to $0{ }^{\circ} \mathrm{C}$ and diluted with $\mathrm{Et}_{2} \mathrm{O}(15 \mathrm{~mL})$. The reaction was quenched by the dropwise addition of $10 \%$ aqueous $\mathrm{K}_{2} \mathrm{CO}_{3}(5 \mathrm{~mL})$ and warmed to ambient temperature. The organic layer was 
separated and washed successively with $10 \%$ aqueous $\mathrm{Na}_{2} \mathrm{~S}_{2} \mathrm{O}_{3}(10 \mathrm{~mL})$ and brine $(10$ $\mathrm{mL}$ ). The organic layer was dried over anhydrous $\mathrm{MgSO}_{4}$, filtered, and concentrated in vacuo. The crude residue was dissolved in THF $(6.70 \mathrm{~mL}, 0.25 \mathrm{M})$ and TBAF $(1.90 \mathrm{~mL}$, 1.0 $\mathrm{M}$ in THF, $1.90 \mathrm{mmol}$ ) was added dropwise via syringe and the reaction mixture was allowed to stir for $14 \mathrm{~h}$. The reaction was quenched by the addition of brine $(3 \mathrm{~mL})$ and the mixture was extracted with $\mathrm{CH}_{2} \mathrm{Cl}_{2}(20 \mathrm{~mL} \times 3)$. The combined organic layers were washed with brine $(50 \mathrm{~mL})$, dried over anhydrous $\mathrm{Na}_{2} \mathrm{SO}_{4}$, filtered, and concentrated in vacuo. The crude residue was dissolved in $\mathrm{MeOH}(8.8 \mathrm{~mL}, 0.2 \mathrm{M})$ and Dowex ${ }^{\circledR} 50 \mathrm{X} 8$ 100 acidic resin $(0.443 \mathrm{~g})$ was added in one-portion and the suspension was allowed to vigorously stir for $12 \mathrm{~h}$. The mixture was filtered and the solvent was removed in vacuo. Purification by flash chromatography $\left(3-5 \% \mathrm{MeOH} / \mathrm{CH}_{2} \mathrm{Cl}_{2}\right)$ on silica gel affords diol $\mathbf{1 k}$ as a light yellow oil $\left(0.235 \mathrm{~g}, 96 \%\right.$ over three steps): ${ }^{1} \mathrm{H}$ NMR $\left(500 \mathrm{MHz}, \mathrm{CDCl}_{3}\right) \delta$ 5.76-5.63 (m, $2 \mathrm{H}), 3.88(\mathrm{~d}, J=5.5 \mathrm{~Hz}, 2 \mathrm{H}), 3.79-3.74(\mathrm{~m}, 1 \mathrm{H}), 3.66(\mathrm{dd}, J=11.2,3.1$ $\mathrm{Hz}, 1 \mathrm{H}), 3.47(\mathrm{dd}, J=11.2,7.2 \mathrm{~Hz}, 1 \mathrm{H}), 3.31(\mathrm{~s}, 3 \mathrm{H}), 2.24(\mathrm{t}, J=6.9 \mathrm{~Hz}, 1 \mathrm{H}) ;{ }^{13} \mathrm{C}$ NMR (125 MHz, $\left.\mathrm{CDCl}_{3}\right) \delta 129.7,129.5,72.9,71.5,66.3,57.9,36.4$; IR (neat) 3379, $2934,1070 \mathrm{~cm}^{-1}$.

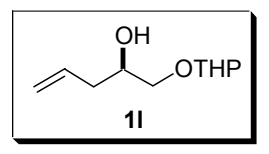

Alkene 1l. A $250 \mathrm{~mL}$ round bottom flask was added a suspension of $\mathrm{CuI}(0.492 \mathrm{~g}, 2.58$ mmol $)$ in $\mathrm{Et}_{2} \mathrm{O}(63.0 \mathrm{~mL}, 0.04 \mathrm{M})$ and cooled to $-15^{\circ} \mathrm{C}(\mathrm{MeOH} / \mathrm{ice})$. Vinylmagnesium bromide $(18.90 \mathrm{~mL}, 1.0 \mathrm{M}$ in THF, $19.90 \mathrm{mmol})$ was added via syringe as a steady stream and the mixture was immediately cooled to $-78^{\circ} \mathrm{C}$. A solution of epoxide $\mathbf{1 g}$ $(1.003 \mathrm{~g}, 6.33 \mathrm{mmol})$ in THF $(6.3 \mathrm{~mL}, 1.0 \mathrm{M})$ was added dropwise via cannula and the 
dark red reaction mixture was covered in foil and allowed to stir at $-78{ }^{\circ} \mathrm{C}$ for $3 \mathrm{~h}$ in the dark. The reaction was warmed to $0{ }^{\circ} \mathrm{C}$ and quenched by the dropwise addition of saturated aqueous $\mathrm{NH}_{4} \mathrm{Cl}(100 \mathrm{~mL})$. The mixture was warmed to ambient temperature and basified to $\mathrm{pH} 9$ with concentrated $\mathrm{NH}_{4} \mathrm{OH}(\mathrm{ca} .4 \mathrm{~mL})$ and vigorously stirred for $12 \mathrm{~h}$ until phase separation is achieved. The organic layer was separated and the aqueous phase was extracted with $\mathrm{Et}_{2} \mathrm{O}(50 \mathrm{~mL} \times 3)$. The combined organic layers were dried over anhydrous $\mathrm{MgSO}_{4}$, filtered, and concentrated in vacuo. Purification by flash chromatography (20\% EtOAc/hexanes) on silica gel affords alkene $\mathbf{1 l}$ (yellow oil) as a mixture of diastereomers $(1.029 \mathrm{~g}, 87 \%):{ }^{1} \mathrm{H}$ NMR $\left(500 \mathrm{MHz}, \mathrm{CDCl}_{3}\right) \delta 5.89-5.81(\mathrm{~m}, 1$ H), 5.14-5.08 (m, 2 H), 4.57-4.56 (m, $1 \mathrm{H}), 3.92-3.79(\mathrm{~m}, 2 \mathrm{H}), 3.76(\mathrm{dd}, J=10.4,3.1$ $\mathrm{Hz}, 0.5 \mathrm{H}), 3.65(\mathrm{dd}, J=11.0,2.8 \mathrm{~Hz}, 0.5 \mathrm{H}), 3.56-3.52(\mathrm{~m}, 1.5 \mathrm{H}), 3.40(\mathrm{dd}, J=10.4$, $7.2 \mathrm{~Hz}, 0.5 \mathrm{H}), 3.18$ (br s, $1 \mathrm{H}), 2.29-2.21$ (m, $2 \mathrm{H}), 1.84-1.81$ (m, $1 \mathrm{H}), 1.77-1.73$ (m, 1 $\mathrm{H}), 1.60-1.53(\mathrm{~m}, 4 \mathrm{H}) ;{ }^{13} \mathrm{C} \mathrm{NMR}\left(125 \mathrm{MHz}, \mathrm{CDCl}_{3}\right) \delta 134.4$ (2), 117.4, 117.5, 100.1 (2), 73.3, 72.3, 69.9 (2), 63.2, 63.0, 38.0, 37.8, 30.8, 30.7, 25.2 (2), 19.9 (2); IR (neat) 3446, $2940,1034 \mathrm{~cm}^{-1}$.

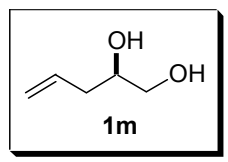

Diol 1m. A $25 \mathrm{~mL}$ round bottom flask was added a solution of alkene $11(0.251 \mathrm{~g}, 1.34$ mmol) in $\mathrm{MeOH}(10.0 \mathrm{~mL}, 0.1 \mathrm{M})$. Dowex ${ }^{\circledR} 50 \mathrm{X} 8-100$ acidic resin $(0.260 \mathrm{~g})$ was added in one-portion and the suspension was allowed to vigorously stir for $14 \mathrm{~h}$. The mixture was filtered and the solvent was removed in vacuo. Purification by flash chromatography $\left(3 \% \mathrm{MeOH} / \mathrm{CH}_{2} \mathrm{Cl}_{2}\right)$ on silica gel affords diol $\mathbf{1 m}$ as a colorless oil $(0.126 \mathrm{~g}, 92 \%)$ : ${ }^{1} \mathrm{H}$ NMR (500 MHz, $\left.\mathrm{CDCl}_{3}\right) \delta$ 5.87-5.78 (m, $\left.1 \mathrm{H}\right)$, 5.15-5.10 (m, $\left.2 \mathrm{H}\right), 3.80-3.76(\mathrm{~m}, 1 \mathrm{H})$, 
3.69-3.65 (m, $1 \mathrm{H}), 3.51-3.47(\mathrm{~m}, 1 \mathrm{H}), 2.30-2.20(\mathrm{~m}, 2 \mathrm{H}) ;{ }^{13} \mathrm{C}$ NMR $(125 \mathrm{MHz}$, $\left.\mathrm{CDCl}_{3}\right) \delta 134.0,118.3,71.1,66.2,37.9$; IR (neat) 3366, 2930, 1070, $1037 \mathrm{~cm}^{-1}$; LRMS (GC-MS/CI) $m / z$ calcd for $\mathrm{C}_{5} \mathrm{H}_{8} \mathrm{O}\left[\mathrm{M}-\mathrm{H}_{2} \mathrm{O}\right]^{+}$84.0, found 83.9.

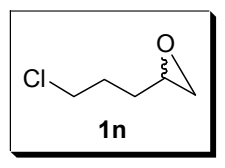

1-Chloro-4,5-epoxypentane 1n. The general procedure for the preparation of chloroepoxides from alkene-ols was performed. 4-Pentene-1-ol (4.012 g, $46.44 \mathrm{mmol})$ and 2,6lutidine (8.10 mL, $69.66 \mathrm{mmol})$ in DMF (47.0 mL); $\mathrm{MsCl}(3.6 \mathrm{~mL}, 46.44 \mathrm{mmol}) ; \mathrm{LiCl}$ (3.111 g, $73.39 \mathrm{mmol})$ was added and stirred for $20 \mathrm{~h}$; quenched with brine $(40 \mathrm{~mL})$; separation funnel contains $\mathrm{Et}_{2} \mathrm{O}(250 \mathrm{~mL})$; washed successively with brine $(200 \mathrm{~mL})$ and $\mathrm{H}_{2} \mathrm{O}(250 \mathrm{~mL} \times 5)$; crude residue was dissolved in $\mathrm{CH}_{2} \mathrm{Cl}_{2}(200.0 \mathrm{~mL}) ; m \mathrm{CPBA}$ (17.667 $\mathrm{g}, 70 \%$ in $\left.\mathrm{H}_{2} 0,71.66 \mathrm{mmol}\right)$ in $\mathrm{CH}_{2} \mathrm{Cl}_{2}(250.0 \mathrm{~mL})$ was added and stirred for $21 \mathrm{~h}$; quenched with $\mathrm{NaHCO}_{3}(300 \mathrm{~mL})$; washed successively with saturated aqueous $\mathrm{NaHCO}_{3}$ $(100 \mathrm{~mL})$ and brine $(100 \mathrm{~mL})$; Purification by flash chromatography $\left(15 \% \mathrm{Et}_{2} \mathrm{O} / \mathrm{hexanes}\right)$ affords 1n (colorless oil, $5.325 \mathrm{~g}, 95 \%$ over two steps). ${ }^{1} \mathrm{H}$ NMR (500 $\left.\mathrm{MHz}, \mathrm{CDCl}_{3}\right) \delta$ 3.64-3.53 (m, 2 H), 2.95-2.93 (m, $1 \mathrm{H}), 2.78-2.76$ (m, $1 \mathrm{H}), 2.51-2.50(\mathrm{~m}, 1 \mathrm{H}), 2.01-$ $1.91(\mathrm{~m}, 2 \mathrm{H}), 1.88-1.78(\mathrm{~m}, 1 \mathrm{H}), 1.63-1.56(\mathrm{~m}, 1 \mathrm{H}) ;{ }^{13} \mathrm{C}$ NMR $\left(125 \mathrm{MHz}, \mathrm{CDCl}_{3}\right) \delta$ 51.5, 46.9, 44.5, 29.7, 29.1; HRMS (EI/isobutane) $\mathrm{m} / \mathrm{z}$ calcd for $\mathrm{C}_{5} \mathrm{H}_{9} \mathrm{O}[\mathrm{M}-\mathrm{Cl}]^{+}$ 85.0653, found 85.0656.

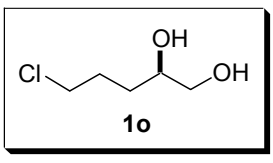

Diol 10. The general procedure for the hydrolytic kinetic resolution of terminal epoxides was performed. Epoxide 1n $(5.039 \mathrm{~g}, 41.79 \mathrm{mmol})$ in THF $(3.0 \mathrm{~mL})$; HOAc $(0.48 \mathrm{~mL}$, 
$8.35 \mathrm{mmol}) ;(S, S)-\mathrm{Co}(\mathrm{II})($ salen $)(0.317 \mathrm{~g}, 0.52 \mathrm{mmol}) ; \mathrm{H}_{2} 0(0.37 \mathrm{~mL}, 20.89 \mathrm{mmol})$ was added and stirred for $43 \mathrm{~h}$; purification by flash chromatography (30\% EtOAc/ $\mathrm{CH}_{2} \mathrm{Cl}_{2}$ ) affords diol $1 \mathrm{o}$ as a orange oil (2.496 g, 43\%): ${ }^{1} \mathrm{H}$ NMR (500 MHz, $\left.\mathrm{CDCl}_{3}\right) \delta$ 3.72-3.68 (m, $1 \mathrm{H}), 3.63(\mathrm{dd}, J=11.3,2.5 \mathrm{~Hz}, 1 \mathrm{H}), 3.57(\mathrm{t}, J=6.3 \mathrm{~Hz}, 2 \mathrm{H}), 3.47(\mathrm{br} \mathrm{s}, 2 \mathrm{H}), 3.42$ (dd, $J=11.3,7.8 \mathrm{~Hz}, 1 \mathrm{H}), 1.99-1.91(\mathrm{~m}, 1 \mathrm{H}), 1.87-1.78(\mathrm{~m}, 1 \mathrm{H}), 1.62-1.48(\mathrm{~m}, 2 \mathrm{H})$; ${ }^{13} \mathrm{C}$ NMR (125 MHz, $\left.\mathrm{CDCl}_{3}\right) \delta$ 71.6, 66.6, 45.0, 30.2, 28.7; IR (neat) 3390, 2932, 1097, $1050 \mathrm{~cm}^{-1}$; HRMS (EI/isobutane) $\mathrm{m} / z$ calcd for $\mathrm{C}_{5} \mathrm{H}_{10} \mathrm{Cl}_{2}[\mathrm{M}-\mathrm{H}]^{+} 137.0369$, found 137.0346.

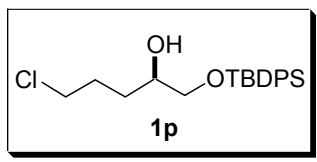

Alcohol 1p. A $10 \mathrm{~mL}$ round bottom flask was added a solution of diol $10(0.023 \mathrm{~g}, 0.16$ mmol), imidazole (0.044 g, $0.65 \mathrm{mmol})$, DMAP $(0.001 \mathrm{~g}, 8.0 \mu \mathrm{mol})$, in DMF $(1.0 \mathrm{~mL}$, $0.2 \mathrm{M})$. TBDPSCl $(0.041 \mathrm{~mL}, 0.16 \mathrm{mmol})$ was added dropwise via syringe and the reaction mixture was allowed to stir for $29 \mathrm{~h}$. The reaction was quenched by the dropwise addition of $10 \%$ aqueous $\mathrm{K}_{2} \mathrm{CO}_{3}(1 \mathrm{~mL})$. The mixture was poured into a separating funnel containing $\mathrm{Et}_{2} \mathrm{O}(30 \mathrm{~mL})$ and washed successively with brine $(10 \mathrm{~mL})$ and $\mathrm{H}_{2} \mathrm{O}(10 \mathrm{~mL} \times 5)$. The organic layer was dried over anhydrous $\mathrm{MgSO}_{4}$, filtered, and concentrated in vacuo. Purification by flash chromatography (10\% EtOAc/hexanes) on silica gel affords $1 \mathbf{p}$ as a colorless oil $(0.058 \mathrm{~g}, 94 \%)$ : ${ }^{1} \mathrm{H}$ NMR $\left(500 \mathrm{MHz}, \mathrm{CDCl}_{3}\right) \delta$ 7.74-7.67 (m, 4 H), 7.47-7.37 (m, 6 H), 3.77-3.72 (m, 1 H), 3.68 (dd, $J=10.2,3.4$ Hz, 1 H), 3.60-3.50 (m, 3 H), 2.51 (br s, 1 H), 1.98-1.91 (m, $1 \mathrm{H}), 1.84-1.78$ (m, $1 \mathrm{H}), 1.61-$ $1.50(\mathrm{~m}, 2 \mathrm{H}), 1.10(\mathrm{~s}, 9 \mathrm{H}) ;{ }^{13} \mathrm{C} \mathrm{NMR}\left(125 \mathrm{MHz}, \mathrm{CDCl}_{3}\right) \delta 135.5,134.7,129.9,127.8$, $71.2,67.9,45.0,30.0,28.7,26.8,19.2$; IR (neat) $3413,2931,2858,1113 \mathrm{~cm}^{-1} ;[\alpha]_{\mathrm{D}}=$ 
$+10.8(c 0.93 \mathrm{EtOH})$. Enantiomeric excess was determined by chiral GC with a $\gamma$ cyclodextrin trifluoroacetyl column $(30 \mathrm{~m} \times 0.25 \mathrm{~mm}) ;($ split ratio $=100: 1 ; 1 \mathrm{~mL} / \mathrm{min}$; initial temp $=50^{\circ} \mathrm{C}$; initial time $=5 \mathrm{~min}$; rate $3{ }^{\circ} \mathrm{C} / \mathrm{min}$; final temp $=150{ }^{\circ} \mathrm{C}$; final time $25 \mathrm{~min})$. HPLC with a Chiralcel OD-H column (10\% iPrOH/hexanes, $1 \mathrm{~mL} / \mathrm{min}, 254$ $\mathrm{nm}) ;(R)$ enantiomer $\mathrm{t}_{\mathrm{r}}=5.21 \min \left(\right.$ major); $(S)$ enantiomer $\mathrm{t}_{\mathrm{r}}=17.00 \min ($ minor); $98 \%$ ee.

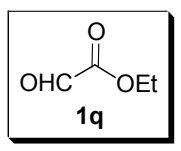

Ethyl glyoxylate 1q. Ethyl glyoxylate XX was synthesized using a literature procedure: Jung, M. E.; Shishido, K.; Davis, L. H. J. Org. Chem. 1982, 47, 891-892

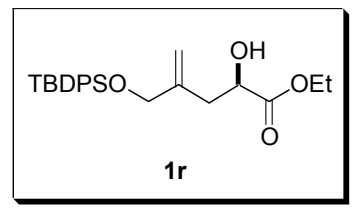

Ester 1r. The title compound was prepared by following a literature method: Evans, D. A.; Burgey, C. S.; Paras, N. A.; Vojkoysky, T.; Tregay, S. W. J. Am. Chem. Soc.1998, 120, 5824-5825. ${ }^{1} \mathrm{H}$ NMR $\left(500 \mathrm{MHz}, \mathrm{CDCl}_{3}\right) \delta$ 7.69-7.67 (m, $\left.4 \mathrm{H}\right), 7.45-7.37(\mathrm{~m}, 6 \mathrm{H})$, $5.24(\mathrm{~s}, 1 \mathrm{H}), 5.01(\mathrm{~s}, 1 \mathrm{H}), 4.30(\mathrm{dd}, J=7.9,4.0 \mathrm{~Hz}, 1 \mathrm{H}), 4.21(\mathrm{dq}, J=7.2,2.0 \mathrm{~Hz}, 2 \mathrm{H})$, 4.15 (s, $2 \mathrm{H}), 3.00$ (br s, $1 \mathrm{H}), 2.61(\mathrm{dd}, J=14.5,3.8 \mathrm{~Hz}, 1 \mathrm{H}), 2.40(\mathrm{dd}, J=14.4,8.0 \mathrm{~Hz}$, $1 \mathrm{H}), 1.27(\mathrm{t}, J=7.3 \mathrm{~Hz}, 3 \mathrm{H}), 1.07$ (s, $9 \mathrm{H}) ;{ }^{13} \mathrm{C} \mathrm{NMR}\left(125 \mathrm{MHz}, \mathrm{CDCl}_{3}\right) \delta 174.3,143.4$, 135.5 (2), 133.3, 129.7, 127.7, 113.5, 69.7, 66.7, 61.6, 38.3, 26.8, 19.2, 14.2; IR (neat) $3457,3072,3052,2958,2930,2857,2251,1732,1009 \mathrm{~cm}^{-1}$; HRMS (ESI) $\mathrm{m} / z$ calcd for $\mathrm{C}_{24} \mathrm{H}_{32} \mathrm{O}_{4} \mathrm{SiNa}[\mathrm{M}+\mathrm{Na}]^{+}$435.1967, found 435.1989; $[\alpha]_{\mathrm{D}}=-1.4\left(c 4.60 \mathrm{CHCl}_{3}\right)$. Enantiomeric excess was determined by HPLC with a Chiralcel OD-H column (1.5\% 
$i \mathrm{PrOH} /$ hexanes, $1 \mathrm{~mL} / \mathrm{min}, 220 \mathrm{~nm}$ ); $(S)$ enantiomer $\mathrm{t}_{\mathrm{r}}=9.24 \mathrm{~min}$ (minor); $(R)$ enantiomer $\mathrm{t}_{\mathrm{r}}=10.59 \min$ (major); $90 \%$ ee.

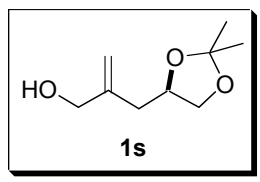

Alcohol 1s. A $50 \mathrm{~mL}$ round bottom flask was added a solution of ester 1r $(0.455 \mathrm{~g}, 1.10$ mmol) in $\mathrm{CH}_{2} \mathrm{Cl}_{2}(12.1 \mathrm{~mL}, 0.1 \mathrm{M})$ and cooled to $-78{ }^{\circ} \mathrm{C}$. DIBAL-H $(4.8 \mathrm{~mL}, 1.0 \mathrm{M}$ in hexane, $4.8 \mathrm{mmol}$ ) was added dropwise via syringe and the reaction mixture was allowed to stir at $-78{ }^{\circ} \mathrm{C}$ for $4 \mathrm{~h}$. The reaction was quenched by the dropwise addition of $\mathrm{HCO}_{3} \mathrm{CH}_{3}(1 \mathrm{~mL})$. The mixture was warmed to ambient temperature and saturated aqueous $\mathrm{NH}_{4} \mathrm{Cl}(10 \mathrm{~mL})$ was added followed by saturated aqueous $\mathrm{NaKC}_{4} \mathrm{H}_{4} \mathrm{O}_{6}(20 \mathrm{~mL})$. The mixture was vigorously stirred for $17 \mathrm{~h}$. The mixture was poured into a separating funnel containing $\mathrm{Et}_{2} \mathrm{O}(100 \mathrm{~mL})$ and washed successively with saturated aqueous $\mathrm{NaHSO}_{4}(20 \mathrm{~mL})$, saturated aqueous $\mathrm{NaHCO}_{3}(20 \mathrm{~mL})$, and brine $(20 \mathrm{~mL})$. The organic layer was dried over anhydrous $\mathrm{MgSO}_{4}$, filtered, and concentrated in vacuo. The crude residue was dissolved in freshly distilled acetone $(10.0 \mathrm{~mL}, 0.1 \mathrm{M}) . \quad 2,2-\mathrm{DMP}(5.0 \mathrm{~mL})$ was added via syringe followed by a catalytic amount of pTSA $(0.090 \mathrm{~g}, 0.47 \mathrm{mmol})$. The reaction mixture was warmed to $58^{\circ} \mathrm{C}$ and allowed to stir for $18 \mathrm{~h}$. The reaction was cooled to ambient temperature and quenched by the dropwise addition of TEA $(0.5 \mathrm{~mL})$. Most of the solvent was removed in vacuo. The mixture was diluted with $\mathrm{Et}_{2} \mathrm{O}(30 \mathrm{~mL})$ and washed successively with saturated aqueous $\mathrm{NaHCO}_{3}(10 \mathrm{~mL})$ and $\mathrm{H}_{2} \mathrm{O}(10 \mathrm{~mL})$. The organic layer was dried over anhydrous $\mathrm{MgSO}_{4}$, filtered, and concentrated in vacuo. The crude residue was dissolved in THF $(4.40 \mathrm{~mL}, 0.25 \mathrm{M})$ and TBAF $(1.20 \mathrm{~mL}, 1.0 \mathrm{M}$ in THF, $1.20 \mathrm{mmol}$ ) was added dropwise via syringe and the reaction mixture was 
allowed to stir for $17 \mathrm{~h}$. The reaction was quenched by the addition of brine $(1 \mathrm{~mL})$ and the mixture was extracted with $\mathrm{CH}_{2} \mathrm{Cl}_{2}(50 \mathrm{~mL} \times 3)$. The combined organic layers were washed with brine $(100 \mathrm{~mL})$, dried over anhydrous $\mathrm{Na}_{2} \mathrm{SO}_{4}$, filtered, and concentrated in vacuo. Purification by flash chromatography (50\% EtOAc/hexanes) on silica gel affords alcohol 1s as a orange oil $\left(0.148 \mathrm{~g}, 78 \%\right.$ over three steps): ${ }^{1} \mathrm{H}$ NMR $\left(500 \mathrm{MHz}, \mathrm{CDCl}_{3}\right) \delta$ $5.11(\mathrm{~s}, 1 \mathrm{H}), 4.94(\mathrm{~s}, 1 \mathrm{H}), 4.25$ (quint, $J=6.8 \mathrm{~Hz}, 1 \mathrm{H}), 4.14-4.06(\mathrm{~m}, 3 \mathrm{H}), 3.58(\mathrm{t}, J=$ $8.1 \mathrm{~Hz}, 1 \mathrm{H}), 2.37$ (d, $J=6.1 \mathrm{~Hz}, 2 \mathrm{H}), 1.65(\mathrm{br} \mathrm{s}, 1 \mathrm{H}), 1.43(\mathrm{~s}, 3 \mathrm{H}), 1.36(\mathrm{~s}, 3 \mathrm{H}) ;{ }^{13} \mathrm{C}$ NMR $\left(125 \mathrm{MHz}, \mathrm{CDCl}_{3}\right) \delta 145.4,113.1,109.2,75.1,69.2,66.3,37.6,26.9,25.6$; IR (neat) $3395,2986,2933,2877,2360,2338,1038 \mathrm{~cm}^{-1}$.

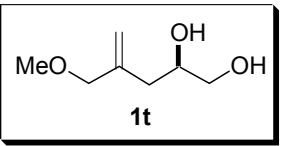

Diol 1t. A $10 \mathrm{~mL}$ round bottom flask was added a suspension of $\mathrm{NaH}(0.064 \mathrm{~g}, 60 \%$ in oil, $1.59 \mathrm{mmol})$ in THF $(1.5 \mathrm{~mL}, 0.5 \mathrm{M})$ and cooled to $0{ }^{\circ} \mathrm{C}$. A solution of alcohol $1 \mathrm{~s}$ $(0.130 \mathrm{~g}, 0.75 \mathrm{mmol})$ in THF $(0.5 \mathrm{~mL})$ was added dropwise via syringe with the evolution of $\mathrm{H}_{2}$ gas. The mixture is warmed to ambient temperature and allowed to stir for $30 \mathrm{~min}$. MeI $(0.23 \mathrm{~mL}, 3.75 \mathrm{mmol})$ was added dropwise via syringe and the flask was covered in foil and allowed to stir for $19 \mathrm{~h}$ in the dark. The mixture was cooled to $0{ }^{\circ} \mathrm{C}$ and diluted with $\mathrm{Et}_{2} \mathrm{O}(5 \mathrm{~mL})$. The reaction was quenched by the dropwise addition of $10 \%$ aqueous $\mathrm{K}_{2} \mathrm{CO}_{3}(1 \mathrm{~mL})$ and warmed to ambient temperature. The organic layer was separated and washed successively with $10 \%$ aqueous $\mathrm{Na}_{2} \mathrm{~S}_{2} \mathrm{O}_{3}(5 \mathrm{~mL})$ and brine $(10$ $\mathrm{mL}$ ). The organic layer was dried over anhydrous $\mathrm{MgSO}_{4}$, filtered, and concentrated in vacuo. The crude residue was dissolved in $\mathrm{MeOH}(4.0 \mathrm{~mL}, 0.2 \mathrm{M})$ and Dowex ${ }^{\circledR} 50 \mathrm{X} 8$ 100 acidic resin $(0.145 \mathrm{~g})$ was added in one-portion and the suspension was allowed to 
vigorously stir for $20 \mathrm{~h}$. The mixture was filtered and the solvent was removed in vacuo. Purification by flash chromatography $\left(5 \% \mathrm{MeOH} / \mathrm{CH}_{2} \mathrm{Cl}_{2}\right)$ on silica gel affords diol $\mathbf{1 t}$ as a light yellow oil (0.095 g, 87\% over two steps); ${ }^{1} \mathrm{H}$ NMR (500 MHz, $\left.\mathrm{CDCl}_{3}\right) \delta 5.12$ (s, 1 H), $5.03(\mathrm{~s}, 1 \mathrm{H}), 3.88(\mathrm{q}, J=11.7 \mathrm{~Hz}, 2 \mathrm{H}), 3.82-3.78(\mathrm{~m}, 1 \mathrm{H}), 3.61(\mathrm{dd}, J=11.2,3.4$ Hz, $1 \mathrm{H}), 3.46$ (dd, $J=11.2,6.8 \mathrm{~Hz}, 1 \mathrm{H}), 3.33$ (s, $3 \mathrm{H}), 3.19-3.11$ (br s, $2 \mathrm{H}), 2.30-2.15$ $(\mathrm{m}, 2 \mathrm{H}) ;{ }^{13} \mathrm{C}$ NMR $\left(125 \mathrm{MHz}, \mathrm{CDCl}_{3}\right) \delta 142.3,117.0,76.4,70.8,66.6,58.1,38.6$; IR (neat) $3400,2929,1090,1036 \mathrm{~cm}^{-1}$.

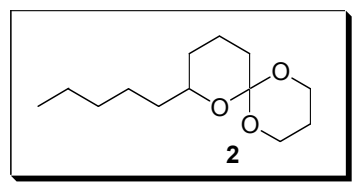

Orthoester 2. 1,3-propane diol (3.05 g, $40 \mathrm{mmol})$ and $\delta$-decanolactone $(5.55 \mathrm{~g}, 33$ mmol) were dissolved in toluene $(100 \mathrm{~mL})$ and CSA (775 mg, $3 \mathrm{mmol})$ was added. The flask was equipped with a Dean-Stark trap and refluxed for 2 days with the azeotropic removal of water. The reaction was then cooled to $0{ }^{\circ} \mathrm{C}$, copious amounts of saturated $\mathrm{NaHCO}_{3}$ were added, and the mixture warmed to room temperature. The mixture was extracted with ether $(3 \times)$, dried $\left(\mathrm{MgSO}_{4}\right)$, and chromatographed (10\% EtOAc/hexanes) to yield the product $(2.34 \mathrm{~g}, 10 \mathrm{mmol}, 31 \%): \mathrm{R}_{\mathrm{f}}=0.49(20 \% \mathrm{EtOAc} / \mathrm{hexanes}) . \quad \mathrm{IR}$ (neat) 2932, 2874, 1245, 1148, 1060, 1038, $978 \mathrm{~cm}^{-1} ;{ }^{1} \mathrm{H}$ NMR (500 MHz, $\left.\mathrm{CDCl}_{3}\right) \delta 4.38$ (ddd, $J=13.3,11.0,2.8,1 \mathrm{H}), 3.99(\mathrm{ddd}, J=13.2,11.0,2.7,1 \mathrm{H}), 3.74(\mathrm{ddt}, J=10.9,5.3$, $1.6,1 \mathrm{H}), 3.68(\mathrm{ddt}, J=10.9,5.2,1.5,1 \mathrm{H}), 3.59-3.54(\mathrm{~m}, 1 \mathrm{H}), 2.10(\mathrm{qt}, J=13.0,5.2,1$ H), 1.84-1.80 (m, $1 \mathrm{H}), 1.76-1.69$ (m, $1 \mathrm{H}), 1.69-1.64$ (m, $1 \mathrm{H}), 1.60-1.54$ (m, $3 \mathrm{H}), 1.51-$ $1.29(\mathrm{~m}, 8 \mathrm{H}), 1.26-1.18(\mathrm{~m}, 1 \mathrm{H}), 0.90(\mathrm{t}, J=6.9,3 \mathrm{H}) ;{ }^{13} \mathrm{C} \mathrm{NMR}\left(125 \mathrm{MHz}, \mathrm{CDCl}_{3}\right) \delta$ $109.3,72.9,59.4,58.3,36.0,34.0,31.9,30.7,25.5,24.8,22.6,20.0,14.1 . \mathrm{MS}$ (HRCI) calcd. for $\mathrm{C}_{13} \mathrm{H}_{25} \mathrm{O}_{3}(\mathrm{M}+\mathrm{H})$ 229.1803; found 229.1802 


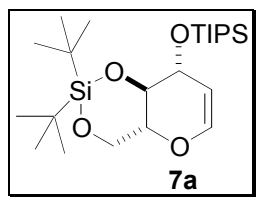

Glucal 7a. Glucal 7a was synthesized using a literature procedure. Georges, A.; Parker, K. Org Lett., 2000, 2, 497.

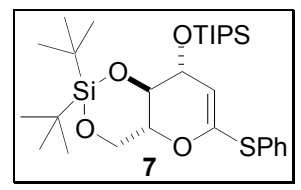

Hemithioketene acetal 7. Glucal 7a $(1.50 \mathrm{~g}, 3.39 \mathrm{mmol})$ was dissolved in $3.39 \mathrm{~mL}$ of THF, the solution was cooled to $-78{ }^{\circ} \mathrm{C}$, and then $t$-BuLi $(1.5 \mathrm{M}$ in pentane, $4.79 \mathrm{~mL}$, $7.45 \mathrm{mmol}$ ) was added to the stirring solution dropwise over a $15 \mathrm{~min}$. period. The reaction mixture, comprised of a bright yellow solution and a fine white suspension, was stirred at $-78{ }^{\circ} \mathrm{C}$ for $15 \mathrm{~min}$, warmed to $0{ }^{\circ} \mathrm{C}$ and stirred for another $2 \mathrm{hrs}$. The now pale yellow solution was cooled to $-78^{\circ} \mathrm{C}$, and a solution of phenyl disulfide $(1.63 \mathrm{~g}, 7.45$ $\mathrm{mmol})$ in THF $(7.45 \mathrm{~mL})$ was added dropwise over a 15 min period. The pale yellow solution was stirred at $-78{ }^{\circ} \mathrm{C}$ for $2 \mathrm{hr}$, and then warmed to room temperature at which time water $(30 \mathrm{~mL})$ was introduced to the reaction mixture. The mixture was extracted with pentane $(3 \times 30 \mathrm{~mL})$, the combined organic layers were washed with brine $(1 \times 20$ $\mathrm{mL}$ ), dried over anhydrous $\mathrm{MgSO}_{4}$, filtered, and concentrated under reduced pressure. The residue was passed through a plug of silica gel eluding with pentane (to remove residual thiophenol, and phenyl disulfide) then $\mathrm{Et}_{2} \mathrm{O}$. The thiophenol and phenyl disulfide free fractions were concentrated and the resulting oil was then purified by flash chromatography (deactivated silica gel) to give $1.74 \mathrm{~g}$ (93\% yield) of the title compound as a colorless oil: $\mathrm{R}_{\mathrm{f}}=0.73(20 \% \text { Hexane/2-methylbutane, deactivated TLC plate); [ }]_{\mathrm{D}}$ $-7.43^{\circ}\left(\right.$ c 3.73, $\left.\mathrm{CHCl}_{3}\right) ;{ }^{1} \mathrm{H} \mathrm{NMR}\left(500 \mathrm{MHz}, \mathrm{CDCl}_{3}\right) \quad 7.38(\mathrm{~m}, 2 \mathrm{H}), 7.31(\mathrm{~m}, 2 \mathrm{H}), 7.26$ 
(m, 1H), $5.02(\mathrm{~d}, 1 \mathrm{H}, J=2.4), 4.46(\mathrm{dd}, 1 \mathrm{H}, J=2.4,6.9), 4.12(\mathrm{~m}, 1 \mathrm{H}), 4.05(\mathrm{dd}, 1 \mathrm{H}, J=$ 6.9, 10.3), $3.98(\mathrm{t}, 1 \mathrm{H}, J=10.4), 3.88(\mathrm{dt}, 1 \mathrm{H}, J=5.0,10.3), 1.07(\mathrm{~m}, 30 \mathrm{H}), 0.99(\mathrm{~s}, 9 \mathrm{H})$ ppm; ${ }^{13} \mathrm{C}$ NMR $\left(125 \mathrm{MHz}, \mathrm{CDCl}_{3}\right) \quad 148.4,132.4,130.8,129.1,127.4,109.6,77.3$, 74.3, 72.1, 65.6, 27.4, 26.9, 22.7, 19.8, 18.1, 12.4 ppm; IR (neat), 2942, 1625, 1584, 1471, 1387, $1109 \mathrm{~cm}^{-1}$; HRMS (ESI) calcd for $\mathrm{C}_{29} \mathrm{H}_{51} \mathrm{O}_{4} \mathrm{SSi}_{2}[\mathrm{M}+\mathrm{H}]^{+}$551.3047; found 551.3029 .

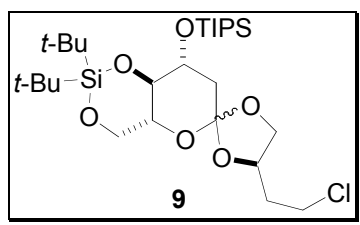

Orthoester 9. To a solution of hemithioketene acetal $7(0.100 \mathrm{~g}, 0.182 \mathrm{mmol})$ in dichloromethane $(1.8 \mathrm{~mL})$, was added a solution of diol $8(0.0270 \mathrm{~g}, 0.217 \mathrm{mmol})$ dissolved in $0.43 \mathrm{~mL}$ of dichloromethane and then CSA $(0.4 \mathrm{mg}, 0.002 \mathrm{mmol})$. The solution was stirred at room temperature for $1 \mathrm{hr}$ then concentrated under reduced pressure and the residue was purified by flash chromatography $\left(10 \% \mathrm{Et}_{2} \mathrm{O} / \mathrm{Pentane}\right)$ to afford $0.0711 \mathrm{~g}$ (69\% yield) of the desired orthoester (colorless oil) as a mixture of two diastereomers (2:1). The isomers were separated by flash chromatograph and characterized: Minor isomer; $\mathrm{R}_{\mathrm{f}}=0.39\left(10 \% \mathrm{Et}_{2} \mathrm{O} / \mathrm{Pentane}\right) ;{ }^{1} \mathrm{H}$ NMR $(500 \mathrm{MHz}$, $\left.\mathrm{CDCl}_{3}\right) \quad 4.45(\mathrm{~m}, 1 \mathrm{H}), 4.21(\mathrm{dd}, 1 \mathrm{H}, J=7.4,7.8), 4.05-4.00(\mathrm{~m}, 2 \mathrm{H}), 3.88-3.82(\mathrm{~m}, 2 \mathrm{H})$, 3.71-3.58 (m, 4H), 2.19-2.12 (m, 2H), 2.02-1.93 (m, 2H), $1.09(\mathrm{~m}, 21 \mathrm{H}), 1.04(\mathrm{~s}, 9 \mathrm{H})$, 0.99 (s, 9H) ppm; ${ }^{13} \mathrm{C}$ NMR (125 MHz, $\left.\mathrm{CDCl}_{3}\right) \quad 119.5,79.2,74.3,71.4,69.5,69.2$, $66.8,41.1,40.8,38.2,27.5,26.9,22.7,19.9,18.2,18.1,12.4 \mathrm{ppm} ;$ Major isomer; $\mathrm{R}_{\mathrm{f}}=$ $0.36\left(10 \% \mathrm{Et}_{2} \mathrm{O} /\right.$ Pentane); ${ }^{1} \mathrm{H}$ NMR $\left(500 \mathrm{MHz}, \mathrm{CDCl}_{3}\right) \quad 4.44(\mathrm{~m}, 1 \mathrm{H}), 4.24(\mathrm{t}, 1 \mathrm{H}, J=$ 7.6), $4.07(\mathrm{dd}, 1 \mathrm{H}, J=5.0,10.0), 4.02(\mathrm{~m}, 1 \mathrm{H}), 3.86(\mathrm{t}, 1 \mathrm{H}, J=10.0), 3.71-3.36(\mathrm{~m}, 5 \mathrm{H})$, 2.14-2.07 (m, 2H), 2.04-1.97 (m, 2H), $1.09(\mathrm{~m}, 21 \mathrm{H}), 1.05(\mathrm{~s}, 9 \mathrm{H}), 0.99(\mathrm{~s}, 9 \mathrm{H}) \mathrm{ppm} ;{ }^{13} \mathrm{C}$ 
NMR (125 MHz, $\left.\mathrm{CDCl}_{3}\right) \quad$ 119.0, 79.1, 72.9, 71.4, 69.4, 69.1, 66.9, 41.1, 40.8, 36.2, 27.5, 27.0, 22.8, 19.9, 18.2, 18.1, 12.5 ppm; IR (neat) 2942, 1471, 1394, 1107, 968, 826 $\mathrm{cm}^{-1}$; HRMS (ESI) calcd for $\mathrm{C}_{27} \mathrm{H}_{54} \mathrm{ClO}_{6} \mathrm{Si}_{2}[\mathrm{M}+\mathrm{H}]^{+}$565.3148; found 565.3128.

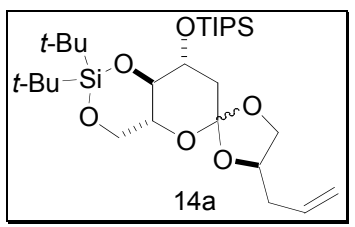

Orthoester 14a. To a solution of hemithioketene acetal $7(0.200 \mathrm{~g}, 0.363 \mathrm{mmol})$ in dichloromethane $(3.6 \mathrm{~mL})$, was added a solution of diol $\mathbf{1 m}(0.0400 \mathrm{~g}, 0.399 \mathrm{mmol})$ dissolved in $0.80 \mathrm{~mL}$ of dichloromethane and then CSA $(0.8 \mathrm{mg}, 0.004 \mathrm{mmol})$ added in one portion. The solution was stirred at room temperature for $1 \mathrm{hr}$, warmed to $40{ }^{\circ} \mathrm{C}$ then stirred for one additional hour. The solution was cooled to room temperature, concentrated under reduced pressure, and the resulting residue was purified by flash chromatography (5\% $\mathrm{Et}_{2} \mathrm{O} /$ Pentane) to afford $0.159 \mathrm{~g}$ ( $81 \%$ yield) of the desired orthoester (colorless oil) as an inseparable mixture of two diastereomers (1:1). The mixture was characterized: $\mathrm{R}_{\mathrm{f}}=0.34\left(5 \% \mathrm{Et}_{2} \mathrm{O} / \mathrm{Pentane}\right) ;{ }^{1} \mathrm{H} \mathrm{NMR}\left(500 \mathrm{MHz}, \mathrm{CDCl}_{3}\right)$ $5.76(\mathrm{~m}, 2 \mathrm{H}), 5.11(\mathrm{~m}, 4 \mathrm{H}), 4.41(\mathrm{~m}, 1 \mathrm{H}), 4.30(\mathrm{~m}, 1 \mathrm{H}), 4.12(\mathrm{~m}, 1 \mathrm{H}), 4.04(\mathrm{~m}, 5 \mathrm{H}), 3.85$ (m, 3H), $3.68(\mathrm{~m}, 4 \mathrm{H}), 3.61(\mathrm{~m}, 1 \mathrm{H}), 2.48(\mathrm{~m}, 1 \mathrm{H}), 2.39(\mathrm{~m}, 1 \mathrm{H}), 2.30(\mathrm{~m}, 2 \mathrm{H}), 2.14(\mathrm{~m}$, 2H), $1.97(\mathrm{~m}, 2 \mathrm{H}), 1.09(\mathrm{~m}, 42 \mathrm{H}), 1.04(\mathrm{~m}, 18 \mathrm{H}), 0.98$ (m, 18H) ppm; ${ }^{13} \mathrm{C}$ NMR (125 $\left.\mathrm{MHz}, \mathrm{CDCl}_{3}\right) \quad 133.3,132.9,119.4,119.1,118.1,117.8,79.3,79.2,76.3,75.1,71.4$, 71.3, 69.2, 69.1, 69.0, 67.9, 67.0, 66.8, 41.0, 40.9, 39.6, 38.1, 27.6, 27.5, 27.0, 26.9, 22.8, 22.7, 19.9, 19.8, 18.2, 18.1, 12.5, 12.4 ppm; IR (neat) 3078, 2894, 1645, 1471, 1387, $1108 \mathrm{~cm}^{-1}$; HRMS (ESI) calcd for $\mathrm{C}_{28} \mathrm{H}_{54} \mathrm{O}_{6} \mathrm{Si}_{2} \mathrm{Na}[\mathrm{M}+\mathrm{Na}]^{+}$565.3357; found 565.3375. 


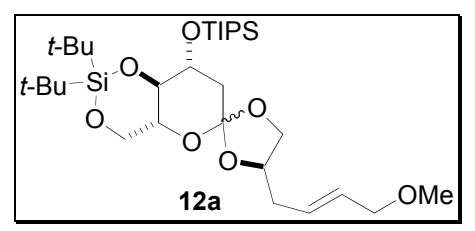

Orthoester 12a. To a solution of hemithioketene acetal $7(0.060 \mathrm{~g}, 0.11 \mathrm{mmol})$ in dichloromethane $(3.6 \mathrm{~mL})$, was added in sequence, a solution of diol 1k $(0.018 \mathrm{~g}, 0.12$ mmol) dissolved in $0.25 \mathrm{~mL}$ of dichloromethane and then CSA (0.8 mg, $0.004 \mathrm{mmol})$. The solution was stirred at room temperature for $1.5 \mathrm{hr}$, concentrated under reduced pressure and the residue was purified by flash chromatography ( $\left.20 \% \mathrm{Et}_{2} \mathrm{O} / \mathrm{Pentane}\right)$ to afford $0.043 \mathrm{~g}$ (67\% yield) of the desired orthoester (colorless oil) as an inseparable mixture of two diastereomers (1.4:1). The mixture was characterized: $R_{\mathrm{f}}=0.34(20 \%$ $\mathrm{Et}_{2} \mathrm{O} /$ Pentane); ${ }^{1} \mathrm{H}$ NMR (500 MHz, $\left.\mathrm{CDCl}_{3}\right) \quad 5.66(\mathrm{~m}, 3.4 \mathrm{H}), 4.40(\mathrm{~m}, 0.7 \mathrm{H}), 4.29(\mathrm{~m}$, $1 \mathrm{H}), 4.13(\mathrm{dd}, 1 \mathrm{H}, J=7.0,7.2), 4.05(\mathrm{~m}, 4.4 \mathrm{H}), 3.86(\mathrm{~m}, 6.6 \mathrm{H}), 3.68(\mathrm{~m}, 3.6 \mathrm{H}), 3.60(\mathrm{~m}$, $0.7 \mathrm{H}), 3.31(\mathrm{~m}, 5.3 \mathrm{H}), 2.49-2.31(\mathrm{~m}, 1.8 \mathrm{H}), 2.15(\mathrm{~m}, 1.7 \mathrm{H}), 2.02-1.92(\mathrm{~m}, 1.8 \mathrm{H}), 1.08$ $(\mathrm{m}, 37.3 \mathrm{H}), 1.04(\mathrm{~m}, 16.7 \mathrm{H}), 0.99(\mathrm{~m}, 16.7 \mathrm{H}) \mathrm{ppm} ;{ }^{13} \mathrm{C} \mathrm{NMR}\left(125 \mathrm{MHz}, \mathrm{CDCl}_{3}\right) \quad 129.9$, 129.6, 128.3, 128.1, 119.4, 119.1, 79.3, 79.2, 76.4, 75.2, 72.8, 72.7, 71.4, 71.3, 69.2, 69.1, $67.9,66.9,66.8,57.9,57.8,41.0,40.9,38.1,36.6,27.6,27.5,27.0,26.9,22.8,22.7,19.9$, 19..8, 18.16, 18.14, 18.12, 18.11, 12.5, $12.4 \mathrm{ppm}$; IR (neat) 2941, 1471, 1397, 1106, 873, $654 \mathrm{~cm}^{-1}$; HRMS (ESI) calcd for $\mathrm{C}_{28} \mathrm{H}_{58} \mathrm{O}_{7} \mathrm{Si}_{2} \mathrm{Na}[\mathrm{M}+\mathrm{Na}]^{+}$609.3619; found 609.3615.

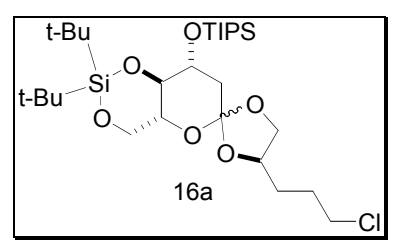

Orthoester 16a. Please see the section that describes the formation of cyano acetal 16b. 


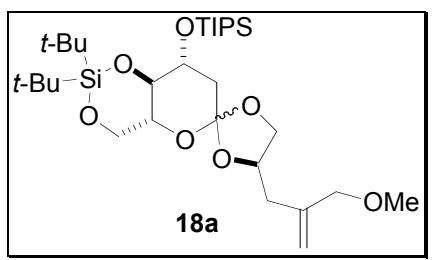

Orthoester 18a. To a solution of hemithioketene acetal $7(0.150 \mathrm{~g}, 0.272 \mathrm{mmol})$ in dichloromethane $(2.7 \mathrm{~mL})$, was added in sequence a solution of diol $1 \mathrm{t}(0.0440 \mathrm{~g}, 0.300$ $\mathrm{mmol})$ dissolved in $0.60 \mathrm{~mL}$ of dichloromethane and then CSA $(0.6 \mathrm{mg}, 0.002 \mathrm{mmol})$ in one portion. The solution was warmed to $40{ }^{\circ} \mathrm{C}$ and stirred at this temperature for $1 \mathrm{hr}$. Triethylamine $(0.0038 \mathrm{~mL}, 0.027 \mathrm{mmol})$ was then added to the reaction vessel and the mixture was stirred at $40{ }^{\circ} \mathrm{C}$ for $12 \mathrm{hrs}$. The mixture was then cooled to room temperature, concentrated under reduced pressure and to the residue was added $3 \mathrm{~mL}$ of dichloromethane, then CSA $(0.0094 \mathrm{~g}, 0.041 \mathrm{mmol})$ and the solution was warmed to 40 ${ }^{\circ} \mathrm{C}$ for $2 \mathrm{hrs}$, cooled to room temperature and the resulting residue was purified by flash chromatography $\left(10 \% \mathrm{Et}_{2} \mathrm{O} / \mathrm{Pentane}\right)$ to afford $0.038 \mathrm{~g}$ (24\% yield) of the desired orthoester (colorless oil) as a mixture of two diastereomers (2:1). The isomers were separated and characterized: Minor isomer; $\mathrm{R}_{\mathrm{f}}=0.23\left(10 \% \mathrm{Et}_{2} \mathrm{O} /\right.$ Pentane $) ;{ }^{1} \mathrm{H} \mathrm{NMR}$ $\left(500 \mathrm{MHz}, \mathrm{CDCl}_{3}\right) \quad 5.10(\mathrm{~s}, 1 \mathrm{H}), 4.99(\mathrm{~s}, 1 \mathrm{H}), 4.34(\mathrm{dq}, 1 \mathrm{H}, J=6.6,13.3), 4.14(\mathrm{dd}$, $1 \mathrm{H}, J=6.5,8.1), 4.07-3.99(\mathrm{~m}, 2 \mathrm{H}), 3.92-3.82(\mathrm{~m}, 3 \mathrm{H}), 3.71-3.58(\mathrm{~m}, 3 \mathrm{H}), 3.31(\mathrm{~s}, 3 \mathrm{H})$, $2.54(\mathrm{dd}, 1 \mathrm{H}, J=6.9,14.7), 2.31(\mathrm{dd}, 1 \mathrm{H}, J=6.7,14.7), 2.15(\mathrm{dd}, 1 \mathrm{H}, J=5.3,13.1), 1.98$ $(\mathrm{dd}, 1 \mathrm{H}, J=11.4,13.5), 1.08(\mathrm{~m}, 21 \mathrm{H}), 1.04(\mathrm{~s}, 9 \mathrm{H}), 0.99(\mathrm{~s}, 9 \mathrm{H}) \mathrm{ppm} ;{ }^{13} \mathrm{C}$ NMR $(125$ $\left.\mathrm{MHz}, \mathrm{CDCl}_{3}\right) \quad 141.8,119.4,114.4,79.1,75.8,75.7,71.3,69.4,68.9,67.0,57.9,41.0$, $38.3,27.6,27.0,22.8,19.9,18.2,18.1,12.5 \mathrm{ppm} ;$ Major isomer; $\mathrm{R}_{\mathrm{f}}=0.13(10 \%$ $\mathrm{Et}_{2} \mathrm{O} /$ Pentane); ${ }^{1} \mathrm{H}$ NMR (500 MHz, $\left.\mathrm{CDCl}_{3}\right) \quad 5.11(\mathrm{~s}, 1 \mathrm{H}), 4.98(\mathrm{~s}, 1 \mathrm{H}), 4.44(\mathrm{~m}, 1 \mathrm{H})$, $4.18(\mathrm{t}, 1 \mathrm{H}, J=7.5), 4.09-4.00(\mathrm{~m}, 2 \mathrm{H}), 3.87(\mathrm{~m}, 3 \mathrm{H}), 3.68(\mathrm{~m}, 1 \mathrm{H}), 3.61(\mathrm{~m}, 2 \mathrm{H}), 3.32$ 
(s, 3H), $2.45(\mathrm{dd}, 1 \mathrm{H}, J=6.7,14.9), 2.29(\mathrm{dd}, 1 \mathrm{H}, J=6.6,14.7), 2.15(\mathrm{dd}, 1 \mathrm{H}, \mathrm{J}=5.2$, 12.9), $1.99(\mathrm{~m}, 1 \mathrm{H}), 1.09(\mathrm{~m}, 21 \mathrm{H}), 1.04(\mathrm{~s}, 9 \mathrm{H}), 0.99(\mathrm{~s}, 9 \mathrm{H}) \mathrm{ppm} ;{ }^{13} \mathrm{C} \mathrm{NMR}(125 \mathrm{MHz}$, $\left.\mathrm{CDCl}_{3}\right) \quad 141.7,119.1,114.6,79.2,75.7,74.1,69.4,69.3,67.0,41.2,37.0,27.6,27.4$, 27.0, 26.9, 22.8, 19.9, 18.2, 18.1, $12.5 \mathrm{ppm}$; IR (neat) 2935, 1472, 1395, 1106, 827, 654 $\mathrm{cm}^{-1}$; HRMS (ESI) calcd for $\mathrm{C}_{30} \mathrm{H}_{58} \mathrm{O}_{7} \mathrm{Si}_{2} \mathrm{Na}[\mathrm{M}+\mathrm{Na}]^{+}$609.3619; found 609.3624.

General procedure for cyano acetal formation: A $10 \mathrm{~mL}$ round bottom flask was added orthoester and azeotroped with benzene. $\mathrm{CH}_{2} \mathrm{Cl}_{2}$ was added via syringe followed by freshly distilled TMSCN and the mixture was cooled to $-40{ }^{\circ} \mathrm{C} . \mathrm{BF}_{3} \cdot \mathrm{OEt}_{2}$ was added dropwise and the reaction mixture was allowed to warm to $-10{ }^{\circ} \mathrm{C}(\mathrm{MeOH} / \mathrm{ice})$ and stirred for a specified period of time. A solution of $10 \%$ aqueous $\mathrm{K}_{2} \mathrm{CO}_{3}(1 \mathrm{~mL})$ was added followed by $\mathrm{MeOH}(1 \mathrm{~mL})$ and the mixture was warmed to $0{ }^{\circ} \mathrm{C}$ and stirred for 1 h. The mixture was poured into a separating funnel containing $\mathrm{Et}_{2} \mathrm{O}(30 \mathrm{~mL})$ and washed with saturated aqueous $\mathrm{NaHCO}_{3}(10 \mathrm{~mL})$. The organic layer was dried over anhydrous $\mathrm{MgSO}_{4}$, filtered, and concentrated in vacuo. Purification by flash chromatography on silica gel affords the title compound.

Formation of Cyano Acetals and Cyclization:

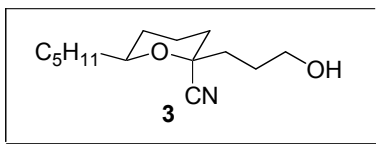

Cyano acetal 3. Orthoester $2(1.59 \mathrm{~g}, 6.96 \mathrm{mmol})$ was azeotroped with benzene, then dissolved in $\mathrm{CH}_{2} \mathrm{Cl}_{2}(35 \mathrm{~mL})$ and cooled to $-78{ }^{\circ} \mathrm{C}$. Trimethylsilyl cyanide $(1.02 \mathrm{~mL}$, $7.66 \mathrm{mmol})$ was added, followed by dropwise addition of $\mathrm{BF}_{3} \cdot \mathrm{OEt}_{2}(0.97 \mathrm{~mL}, 7.66$ mmol). The reaction was stirred for $13 \mathrm{~h}$ at $-78{ }^{\circ} \mathrm{C}$, then warmed to room temperature 
for $1 \mathrm{~h}$, and quenched by addition of $\mathrm{NEt}_{3}$. Saturated $\mathrm{NaHCO}_{3}$ was added and the biphasic mixture stirred for $2 \mathrm{~h}$ (to desilylate any TMS-protected hydroxyls). The layers were separated, and the organic phase dried $\left(\mathrm{Na}_{2} \mathrm{SO}_{4}\right)$. Chromatography with $\mathrm{NEt}_{3}$ treated silica gel (20\% EtOAc/hexanes) afforded the product (1.34 g, $5.24 \mathrm{mmol}, 75 \%)$ : $R_{\mathrm{f}}=0.21$ (20\% EtOAc/hexanes). IR (neat) 3400, 2934, 2871, 1460, 1336, 1190, 1120, 1027, $977 \mathrm{~cm}^{-1} ;{ }^{1} \mathrm{H}$ NMR (500 MHz, $\left.\mathrm{CDCl}_{3}\right) \delta 4.09(\mathrm{ddd}, J=9.7,6.9,5.5,1 \mathrm{H}), 3.90$ (ddd, J= 9.6, 5.9, 5.5, $1 \mathrm{H}), 3.76-3.70(\mathrm{~m}, 3 \mathrm{H}), 2.06-2.03(\mathrm{~m}, 1 \mathrm{H}), 1.91-1.87(\mathrm{~m}, 4 \mathrm{H})$, 1.87-1.76 (app qt, $1 \mathrm{H}), 1.65-1.58$ (m, $4 \mathrm{H}), 1.49-1.18(\mathrm{~m}, 7 \mathrm{H}), 0.89(\mathrm{t}, J=6.9,3 \mathrm{H}) ;{ }^{13} \mathrm{C}$ NMR $\left(125 \mathrm{MHz}, \mathrm{CDCl}_{3}\right) \delta 116.2,97.8,76.5,63.7,60.1,35.4,35.0,32.0,31.6,29.7$, 24.9, 22.5, 20.4, 14.0. MS (LR-EI) calcd. for $\mathrm{C}_{13} \mathrm{H}_{24} \mathrm{O}_{3} \mathrm{Na}(\mathrm{M}-\mathrm{HCN}+\mathrm{Na})$ 251.16; found 251.15 .

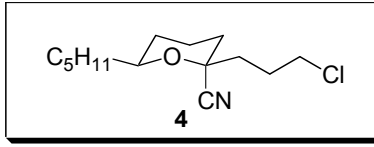

Cyano acetal 4. Cyano acetal 3 (410 mg, $1.6 \mathrm{mmol})$ was dissolved in $\mathrm{CH}_{2} \mathrm{Cl}_{2}(10 \mathrm{~mL})$ and cooled to $0{ }^{\circ} \mathrm{C}$. Pyridine $(0.39 \mathrm{~mL}, 4.8 \mathrm{mmol})$ was added followed by methanesulfonyl chloride $(0.25 \mathrm{~mL}, 3.2 \mathrm{mmol})$ and the reaction was stirred for $3 \mathrm{~h}$, warming gradually to room temperature in the process. Water was added, and the layers were separated. The aqueous layer was extracted with $\mathrm{CH}_{2} \mathrm{Cl}_{2}(3 \times)$, dried $\left(\mathrm{Na}_{2} \mathrm{SO}_{4}\right)$, and concentrated to a white, gelatinous solid. This solid was dissolved in DMF (10 mL), and lithium chloride (730 mg, $17.2 \mathrm{mmol}$ ) was added as a solid. After $17 \mathrm{~h}$, water and $\mathrm{CH}_{2} \mathrm{Cl}_{2}$ were added and the layers were separated. The aqueous layer was extracted with $\mathrm{CH}_{2} \mathrm{Cl}_{2}(3 \times)$, dried $\left(\mathrm{Na}_{2} \mathrm{SO}_{4}\right)$, and chromatographed with silica gel pretreated with $\mathrm{NEt}_{3}$ (10\% EtOAc/hexanes) to afford the product as a yellow oil $(358 \mathrm{mg}, 1.3 \mathrm{mmol}, 82 \%$ 
yield for two steps): ${ }^{1} \mathrm{H}$ NMR $\left(500 \mathrm{MHz}, \mathrm{CDCl}_{3}\right) \delta 4.07(\mathrm{ddd}, J=9.8,5.8,5.8,1 \mathrm{H})$, 3.87 (ddd, $J=9.8,6.0,6.0,1 \mathrm{H}), 3.74-3.69(\mathrm{~m}, 1 \mathrm{H}), 3.62(\mathrm{t}, J=6.5,2 \mathrm{H}), 2.11-2.01(\mathrm{~m}$, $3 \mathrm{H}), 1.90-1.87$ (m, $1 \mathrm{H}), 1.83-1.75$ (app qt, $1 \mathrm{H}), 1.65-1.56$ (m, $3 \mathrm{H}), 1.48-1.19$ (m, $8 \mathrm{H})$, $0.88(\mathrm{t}, J=6.9,3 \mathrm{H}) ;{ }^{13} \mathrm{C} \mathrm{NMR}\left(125 \mathrm{MHz}, \mathrm{CDCl}_{3}\right) \delta$ 116.2, 97.8, 76.3, 62.6, 41.4, 35.4, $34.9,32.5,31.5,29.7,24.8,22.5,20.4,14.0$.

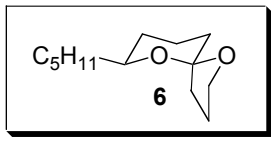

Contrathermodynamic spiroacetal 6. Chloride 4 (42 mg, $0.15 \mathrm{mmol})$ was dissolved in THF ( $2 \mathrm{~mL})$ and cooled to $-78{ }^{\circ} \mathrm{C}$. A solution of LiDBB was added dropwise until the deep green color persisted. The reaction was stirred at $-78{ }^{\circ} \mathrm{C}$ for $1 \mathrm{~h}$, and was then quenched with $\mathrm{MeOH}(250 \mu \mathrm{L})$. Saturated $\mathrm{NaHCO}_{3}$ was added, the solution was diluted with $\mathrm{Et}_{2} \mathrm{O}$, and the layers were separated. The aqueous layer was extracted with $\mathrm{Et}_{2} \mathrm{O}$ (3x), dried $\left(\mathrm{MgSO}_{4}\right)$, and chromatographed $\left(20 \% \mathrm{CH}_{2} \mathrm{Cl}_{2} /\right.$ hexanes followed by $5 \%$ EtOAc/hexanes) to yield the product $(20 \mathrm{mg}, 0.10 \mathrm{mmol}, 63 \%): \mathrm{R}_{\mathrm{f}}=0.30(10 \%$ EtOAc/hexanes): ${ }^{1} \mathrm{H}$ NMR (500 MHz, $\left.\mathrm{CDCl}_{3}\right) \delta 4.05$ (ddd, $\left.J=8.0,8.0,5.5,1 \mathrm{H}\right), 3.89$ (ddd, $J=7.3,7.3,7.3,1 \mathrm{H}), 3.39-3.35(\mathrm{~m}, 1 \mathrm{H}), 2.22(\mathrm{ddd}, J=12.4,8.1,4.1,1 \mathrm{H}), 2.01$ 1.97 (m, $1 \mathrm{H}), 1.89-1.80(\mathrm{~m}, 2 \mathrm{H}), 1.72-1.62(\mathrm{~m}, 2 \mathrm{H}), 1.57-1.17$ (m, $12 \mathrm{H}), 0.87(\mathrm{t}, J=$ $7.0 \mathrm{~Hz}, 3 \mathrm{H}) ;{ }^{13} \mathrm{C}$ NMR $\left(125 \mathrm{MHz}, \mathrm{CDCl}_{3}\right) \delta$ 107.6, 74.3, 67.6, 36.3, 34.2, 32.1, 31.8, $31.1,25.4,24.3,22.7,22.0,14.1$.

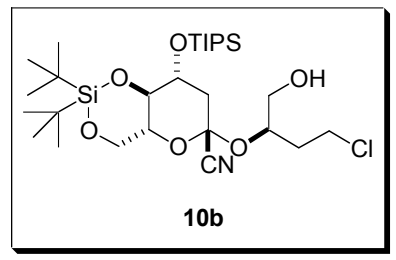


Cyano acetal 10b. The general procedure for cyano acetal formation was performed. Orthoester 9 (0.013 g, $0.023 \mathrm{mmol}) ; \mathrm{CH}_{2} \mathrm{Cl}_{2}(0.50 \mathrm{~mL}, 0.05 \mathrm{M})$; TMSCN $(0.005 \mathrm{~mL}$, $0.052 \mathrm{mmol}) ; \mathrm{BF}_{3} \cdot \mathrm{OEt}_{2}(0.007 \mathrm{~mL}, 0.052 \mathrm{mmol})$ was added and stirred for $1.0 \mathrm{~h}$; purification by flash chromatography (8\% EtOAc/hexanes) affords $\mathbf{1 0 b}$ (colorless oil) as a 6:1 mixture of diastereomers $(0.013 \mathrm{~g}, 92 \%)$ : ${ }^{1} \mathrm{H}$ NMR $\left(500 \mathrm{MHz}, \mathrm{CDCl}_{3}\right) \delta 4.33-4.31$ (m, $1 \mathrm{H}), 4.19-4.17(\mathrm{~m}, 1 \mathrm{H}), 4.08-4.03(\mathrm{~m}, 1 \mathrm{H}), 3.90(\mathrm{t}, J=9.7 \mathrm{~Hz}, 1 \mathrm{H}), 3.75-3.72(\mathrm{~m}$, $3 \mathrm{H}), 3.63(\mathrm{t}, J=6.3 \mathrm{~Hz}, 1 \mathrm{H}), 3.56(\mathrm{dd}, J=7.3,5.6 \mathrm{~Hz}, 1 \mathrm{H}), 2.46(\mathrm{dt}, J=13.6,4.9 \mathrm{~Hz}, 1$ H), 2.21-2.17 (m, 1 H), 2.07-2.04 (m, 2 H), 1.94 (dd, $J=13.6,11.5 \mathrm{~Hz}, 1 \mathrm{H}), 1.25$ (br s, $1 \mathrm{H}), 1.10(\mathrm{~s}, 21 \mathrm{H}), 1.05$ (s, $9 \mathrm{H}), 1.00(\mathrm{~s}, 9 \mathrm{H}) ;{ }^{13} \mathrm{C} \mathrm{NMR}\left(125 \mathrm{MHz}, \mathrm{CDCl}_{3}\right) \delta$ 114.9, $96.1,78.2,71.5,70.4,66.1,64.8,44.3,40.5,34.8,27.5,27.0,22.7,20.0,18.1,12.4$; IR (neat) $3340,2941,2865,2362,1109 \mathrm{~cm}^{-1}$; HRMS (ESI) $\mathrm{m} / z$ calcd for $\mathrm{C}_{28} \mathrm{H}_{54} \mathrm{ClNO}_{6} \mathrm{Si}_{2} \mathrm{Na}$ $[\mathrm{M}+\mathrm{Na}]^{+}$614.3076, found 614.3073.

General procedure for TBS ether formation of cyano acetals: A $10 \mathrm{~mL}$ round bottom flask was added a solution of cyano acetal, imidazole, and DMAP, in DMF. TBSCl was added in one-portion and the reaction mixture was allowed to stir for a specified period of time. The reaction was quenched by the dropwise addition of $10 \%$ aqueous $\mathrm{K}_{2} \mathrm{CO}_{3}(1$ $\mathrm{mL})$. The mixture was poured into a separating funnel containing $\mathrm{Et}_{2} \mathrm{O}(30 \mathrm{~mL})$ and washed successively with brine $(10 \mathrm{~mL})$ and $\mathrm{H}_{2} \mathrm{O}(10 \mathrm{~mL} \times 5)$. The organic layer was dried over anhydrous $\mathrm{MgSO}_{4}$, filtered, and concentrated in vacuo. Purification by flash chromatography on silica gel affords the title compound.

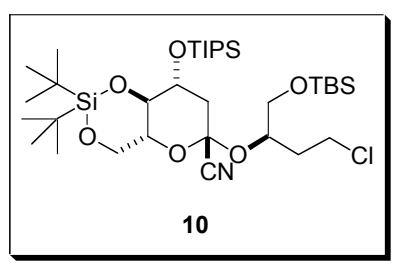


Cyano acetal 10. The general procedure for TBS ether formation of cyano acetals was performed. Cyano acetal 10b (0.013 g, $0.021 \mathrm{mmol})$; imidazole (0.013 g, $0.188 \mathrm{mmol})$; DMAP (0.008 g, $0.066 \mathrm{mmol})$; DMF (0.50 mL, $0.04 \mathrm{M})$; TBSCl (0.017 g, $0.110 \mathrm{mmol})$ was added and the reaction mixture was stirred for $21 \mathrm{~h}$; purification by flash chromatography (2\% $\mathrm{Et}_{2} \mathrm{O} /$ hexanes) affords a $6: 1$ mixture of diastereomers of $\mathbf{1 0}$ as a colorless oil $(0.015 \mathrm{~g}, 99 \%)$ : ${ }^{1} \mathrm{H} \mathrm{NMR}\left(500 \mathrm{MHz}, \mathrm{CDCl}_{3}\right) \delta$ 4.22-4.16 (m, $\left.1 \mathrm{H}\right), 4.14-$ $4.09(\mathrm{~m}, 1 \mathrm{H}), 4.07-4.02(\mathrm{~m}, 1 \mathrm{H}), 3.89(\mathrm{t}, J=8.2 \mathrm{~Hz}, 1 \mathrm{H}), 3.81-3.62(\mathrm{~m}, 4 \mathrm{H}), 3.50(\mathrm{dd}$, $J=10.4,7.2 \mathrm{~Hz}, 1 \mathrm{H}), 2.41(\mathrm{dd}, J=13.6,4.9 \mathrm{~Hz}, 1 \mathrm{H}), 2.43-2.18(\mathrm{~m}, 1 \mathrm{H}), 2.07-2.04$ (m, $2 \mathrm{H}), 1.86(\mathrm{dd}, J=13.6,11.5 \mathrm{~Hz}, 1 \mathrm{H}), 1.10(\mathrm{~s}, 21 \mathrm{H}), 1.05(\mathrm{~s}, 9 \mathrm{H}), 1.00(\mathrm{~s}, 9 \mathrm{H})$, $0.88(\mathrm{~s}, 9 \mathrm{H}) ;{ }^{13} \mathrm{C}$ NMR $\left(125 \mathrm{MHz}, \mathrm{CDCl}_{3}\right) \delta$ 115.6, 96.7, 78.1, 71.3, 70.4, 66.2, 65.2, 44.2, 41.0, 35.4, 27.4, 26.9, 25.8, 22.7, 20.0, 18.3, 18.1, 12.4, -5.4; IR (neat) 2936, 2893, 2864, 1109, $1066 \mathrm{~cm}^{-1}$; HRMS (ESI) $\mathrm{m} / z$ calcd for $\mathrm{C}_{34} \mathrm{H}_{68} \mathrm{ClNO}_{6} \mathrm{Si}_{3} \mathrm{Na}[\mathrm{M}+\mathrm{Na}]^{+}$ 728.3940, found 728.3940 .

Preparation of a stock solution of LiDBB in THF (ca. 0.4 M). A 2-neck round bottom flask equipped with a glass stir bar was added a solution of 4,4'-Di-tert-butylbiphenyl (DBB) $(0.747 \mathrm{~g}, 2.72 \mathrm{mmol})$ in THF $(6.8 \mathrm{~mL})$ and stirred under a stream of Ar. A few crystals of 1,10-phenanthroline were added and the mixture was cooled to $0{ }^{\circ} \mathrm{C}$. The mixture was titrated with $n \mathrm{BuLi}$ until a dark red color persisted. Fresh lithium metal (32.5 mmol) was prepared by submerging the metal in hexanes while scraping off the oxidized surface with an Exacto ${ }^{\boxplus}$ knife. Using scissors, the shiny metal was cut directly into the mixture over a blanket of Ar, forming a dark green color within 5 minutes. The resulting mixture was continued to stir at $0{ }^{\circ} \mathrm{C}$ for $5 \mathrm{~h}$ to provide a $0.4 \mathrm{M}$ solution of LiDBB. 
General procedure for the reductive decyanation alkyllithium cyclization: A $10 \mathrm{~mL}$ cone shaped flask was added the cyclization precursor and azeotroped with benzene ( $x$ 3). Degassed THF was added via syringe and the mixture was added dropwise to a precooled solution of LiDBB (0.4-0.2 M in THF). The reaction mixture was allowed to stir for a specified period of time. The reaction and excess lithium metal was quenched by the dropwise addition of $\mathrm{MeOH}(0.2 \mathrm{~mL})$ and the mixture was slowly warmed to ambient temperature. The mixture was poured into a separating funnel containing $\mathrm{Et}_{2} \mathrm{O}(30 \mathrm{~mL})$ and washed with saturated aqueous $\mathrm{NH}_{4} \mathrm{Cl}(10 \mathrm{~mL})$. The organic layer was dried over anhydrous $\mathrm{MgSO}_{4}$, filtered, and concentrated in vacuo. Purification by flash chromatography on silica gel affords the title compound.

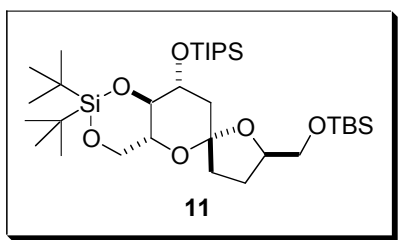

Spiroacetal 11 from precursor 10. The general procedure for reductive decyanation alkyllithium cyclization was performed with the following modifications: A $10 \mathrm{~mL}$ round bottom flask was added the cyclization precursor $10(0.015 \mathrm{~g}, 0.020 \mathrm{mmol})$ and azeotroped with benzene $(\times 3)$. Degassed THF $(0.20 \mathrm{~mL}, 0.6 \mathrm{M})$ was added via syringe and the mixture was cooled to $-78{ }^{\circ} \mathrm{C}$. A solution of LiDBB $(0.17 \mathrm{~mL}, 0.4 \mathrm{M}$ in THF, $0.05 \mathrm{mmol}$ ) was added slowly down the side of the flask and the reaction mixture was allowed to stir at $-78{ }^{\circ} \mathrm{C}$ for $30 \mathrm{~min}$. Purification by flash chromatography (2\% $\mathrm{Et}_{2} \mathrm{O} /$ hexanes) affords 11 as a colorless oil $(0.013 \mathrm{~g}, 98 \%)$ : ${ }^{1} \mathrm{H} \mathrm{NMR}\left(500 \mathrm{MHz}, \mathrm{CDCl}_{3}\right)$ $\delta 4.12$ (quint, $J=7.1 \mathrm{~Hz}, 1 \mathrm{H}), 4.02(\mathrm{dd}, J=9.6,5.3 \mathrm{~Hz}, 1 \mathrm{H}), 3.90(\mathrm{t}, J=10.2 \mathrm{~Hz}, 1 \mathrm{H})$, 3.82-3.79 (m, $1 \mathrm{H}), 3.77(\mathrm{dd}, J=9.6,5.3 \mathrm{~Hz}, 1 \mathrm{H}), 3.67(\mathrm{t}, J=8.6 \mathrm{~Hz}, 1 \mathrm{H}), 3.51(\mathrm{dd}, J=$ 
10.1, 7.1 Hz, $1 \mathrm{H}), 3.30$ (dt, $J=10.3,5.4 \mathrm{~Hz}, 1 \mathrm{H}), 2.31$ (dd, $J=5.1,3.3 \mathrm{~Hz}, 1 \mathrm{H}), 2.06-$ 1.95 (m, $3 \mathrm{H}), 1.82-1.77$ (m, $1 \mathrm{H}), 1.66-1.61$ (m, $1 \mathrm{H}), 1.08$ (s, $21 \mathrm{H}), 1.04$ (s, $9 \mathrm{H}), 0.98$ (s, $9 \mathrm{H}), 0.88(\mathrm{~s}, 9 \mathrm{H}), 0.05(\mathrm{~s}, 6 \mathrm{H}) ;{ }^{13} \mathrm{C} \mathrm{NMR}\left(125 \mathrm{MHz}, \mathrm{CDCl}_{3}\right) \delta$ 107.4, 80.4, 79.6, $71.9,70.9,67.4,66.8,43.5,32.6,29.7,27.6,27.0,26.0,22.7,19.9,18.4,18.1,12.5,-5.4$; IR (neat) 2930, 2893, 2860, 1100, $1067 \mathrm{~cm}^{-1}$; HRMS (ESI) $\mathrm{m} / z$ calcd for $\mathrm{C}_{33} \mathrm{H}_{68} \mathrm{O}_{6} \mathrm{Si}_{3} \mathrm{Na}$ $[\mathrm{M}+\mathrm{Na}]^{+}$667.4221, found 667.4232 .

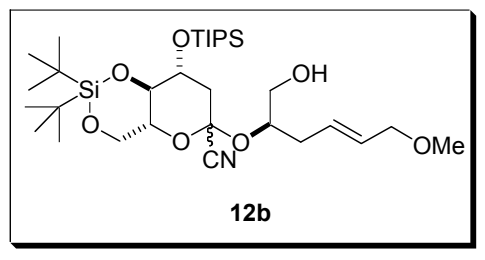

Cyano acetal 12b. The general procedure for cyano acetal formation was performed. Orthoester 12a $(0.050 \mathrm{~g}, 0.085 \mathrm{mmol}) ; \mathrm{CH}_{2} \mathrm{Cl}_{2}(0.70 \mathrm{~mL}, 0.12 \mathrm{M})$; TMSCN $(0.030 \mathrm{~mL}$, $0.286 \mathrm{mmol}) ; \mathrm{BF}_{3} \cdot \mathrm{OEt}_{2}(0.032 \mathrm{~mL}, 0.255 \mathrm{mmol})$ was added and stirred for $1.0 \mathrm{hr}$; purification by flash chromatography (20\% EtOAc/hexanes) affords $\mathbf{1 2 b}$ (colorless oil) as a 1:1 mixture of diastereomers $(0.051 \mathrm{~g}, 98 \%):{ }^{1} \mathrm{H}$ NMR $\left(500 \mathrm{MHz}, \mathrm{CDCl}_{3}\right) \delta 5.70-5.60$ (m, $2 \mathrm{H}), 4.18-4.11(\mathrm{~m}, 2 \mathrm{H}), 4.07-4.05(\mathrm{~m}, 1 \mathrm{H}), 3.92-3.88(\mathrm{~m}, 2.5 \mathrm{H}), 3.85(\mathrm{t}, J=4.5$ $\mathrm{Hz}, 1.5 \mathrm{H}), 3.75(\mathrm{dd}, J=12.1,3.8 \mathrm{~Hz}, 0.5 \mathrm{H}), 3.71-3.66(\mathrm{~m}, 2 \mathrm{H}), 3.62(\mathrm{dd}, J=12.2,5.8$ $\mathrm{Hz}, 0.5 \mathrm{H}), 3.33(\mathrm{~d}, J=3.0 \mathrm{~Hz}, 3 \mathrm{H}), 2.46(\mathrm{dt}, J=13.6,4.9 \mathrm{~Hz}, 1 \mathrm{H}), 2.38(\mathrm{t}, J=6.6 \mathrm{~Hz}$, $1 \mathrm{H}), 2.28(\mathrm{q}, J=6.4 \mathrm{~Hz}, 1 \mathrm{H}), 1.94-1.88(\mathrm{~m}, 1 \mathrm{H}), 1.25(\mathrm{br} \mathrm{s}, 1 \mathrm{H}), 1.09$ (s, $21 \mathrm{H}), 1.05$ (s, $9 \mathrm{H}), 0.99$ (s, $9 \mathrm{H}) ;{ }^{13} \mathrm{C}$ NMR $\left(125 \mathrm{MHz}, \mathrm{CDCl}_{3}\right) \delta 130.1,129.7,128.7,128.5,115.7$, $114.9,96.5,96.0,78.7,78.2,72.8(2), 71.3(2), 70.4(2), 69.3,66.2,66.1,63.7,57.9,44.2$, 43.8, 36.3, 35.4, 27.5, 27.4, 26.9 (2), 22.7, 19.9 (2), 18.1 (2), 12.4; IR (neat) 3440, 2940, 2893, 2865, 1109, $1070 \mathrm{~cm}^{-1}$; HRMS (ESI) $\mathrm{m} / z$ calcd for $\mathrm{C}_{31} \mathrm{H}_{59} \mathrm{NO}_{7} \mathrm{Si}_{2} \mathrm{Na}[\mathrm{M}+\mathrm{Na}]^{+}$ 636.3728, found 636.3752 . 


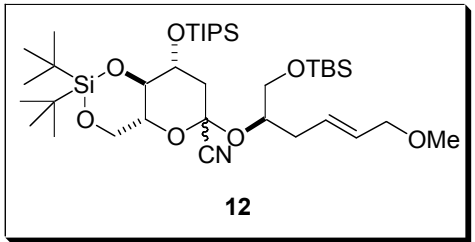

Cyano acetal 12. The general procedure for TBS ether formation of cyano acetals was performed. Cyano acetal 12b (0.051 g, $0.083 \mathrm{mmol})$; imidazole $(0.023 \mathrm{~g}, 0.332 \mathrm{mmol})$; DMAP (0.007 g, $0.050 \mathrm{mmol})$; DMF (3.00 mL, $0.03 \mathrm{M})$; TBSCl (0.043 g, $0.286 \mathrm{mmol})$ was added and the reaction mixture was stirred for $23 \mathrm{~h}$; purification by flash chromatography ( $5 \% \mathrm{Et}_{2} \mathrm{O} /$ hexanes) affords a 1:1 mixture of diastereomers of $\mathbf{1 2}$ as a colorless oil $(0.059 \mathrm{~g}, 97 \%):{ }^{1} \mathrm{H}$ NMR $\left(500 \mathrm{MHz}, \mathrm{CDCl}_{3}\right) \delta$ 5.67-5.58 (m, $\left.2 \mathrm{H}\right), 4.17-$ $4.15(\mathrm{~m}, 1 \mathrm{H}), 4.08-4.05(\mathrm{~m}, 1.5 \mathrm{H}), 3.92-3.86(\mathrm{~m}, 3.5 \mathrm{H}), 3.74-3.60$ (m, $4 \mathrm{H}), 3.31$ (s, 3 H), 2.43-2.17 (m, $3 \mathrm{H}), 1.90-1.85$ (m, $1 \mathrm{H}), 1.09$ (s, $21 \mathrm{H}), 1.05$ (s, $9 \mathrm{H}), 0.99$ (s, $9 \mathrm{H})$, 0.90 (s, $9 \mathrm{H}), 0.06(\mathrm{~s}, 6 \mathrm{H}) ;{ }^{13} \mathrm{C} \mathrm{NMR}\left(125 \mathrm{MHz}, \mathrm{CDCl}_{3}\right) \delta 129.4$ (2), 129.2 (2), 115.6, 115.0, 96.5, 96.0, 78.3, 78.2, 73.0 (2), 71.2, 71.1, 70.5, 70.4 (3), 66.3, 66.2, 63.8, 57.8, $44.3,43.9,37.5,27.4,26.9,25.8$ (2), 22.7 (2), 20.0 (2), 18.3, 18.1 (2), 18.0, 12.4, -5.4 (2); IR (neat) 2936, 2892, 2864, 1108, $1070 \mathrm{~cm}^{-1}$; HRMS (ESI) $\mathrm{m} / z$ calcd for $\mathrm{C}_{37} \mathrm{H}_{73} \mathrm{NO}_{7} \mathrm{Si}_{3} \mathrm{Na}[\mathrm{M}+\mathrm{Na}]^{+} 750.4593$, found 750.4614 .

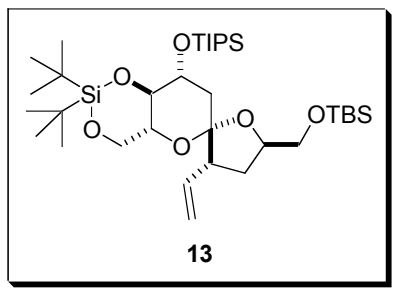

Spiroacetal 13 from precursor 12. The general procedure for reductive decyanation alkyllithium cyclization was performed. Cyclization precursor 12 (0.021 g, $0.028 \mathrm{mmol})$; THF (0.20 mL, 0.1 M); solution of LiDBB (1.50 mL, 0.2 M in THF, $0.36 \mathrm{mmol})$ was precooled to $-78{ }^{\circ} \mathrm{C}$; the reaction mixture was allowed to stir at $-78{ }^{\circ} \mathrm{C}$ for $30 \mathrm{~min}$; 
purification by flash chromatography ( $2 \% \mathrm{Et}_{2} \mathrm{O} /$ hexanes) affords $\mathbf{1 3}$ as a colorless oil (0.017 g, 88\%): ${ }^{1} \mathrm{H}$ NMR (500 MHz, $\left.\mathrm{CDCl}_{3}\right) \delta$ 5.68-5.57 (m, $\left.1 \mathrm{H}\right), 5.03-4.99(\mathrm{~m}, 2 \mathrm{H})$, 4.09-3.97 (m, $3 \mathrm{H}), 3.82(\mathrm{t}, J=10.0 \mathrm{~Hz}, 1 \mathrm{H}), 3.72-3.69(\mathrm{~m}, 2 \mathrm{H}), 3.65-3.63(\mathrm{~m}, 2 \mathrm{H})$, 2.67-2.62 (m, $1 \mathrm{H}), 2.26-2.21(\mathrm{~m}, 1 \mathrm{H}), 1.88(\mathrm{dd}, J=10.1,7.3 \mathrm{~Hz}, 2 \mathrm{H}), 1.55(\mathrm{dd}, J=$ 11.1, $7.3 \mathrm{~Hz}, 1 \mathrm{H}), 1.26$ (s, $21 \mathrm{H}), 1.04$ (s, $9 \mathrm{H}), 0.99$ (s, $9 \mathrm{H}), 0.90$ (s, $9 \mathrm{H}), 0.07$ (s, $6 \mathrm{H})$; ${ }^{13} \mathrm{C}$ NMR $\left(125 \mathrm{MHz}, \mathrm{CDCl}_{3}\right) \delta$ 138.2, 115.8, 108.2, 79.9, 78.2, 71.2, 67.9, 66.9, 65.6, $52.8,40.6,32.7,29.7,27.6,27.1,25.9,22.8,19.9,18.3,18.2,12.5,-5.1$; IR (neat) 2958, 2928, 2859, 1103, $1067 \mathrm{~cm}^{-1}$; HRMS (ESI) $\mathrm{m} / z$ calcd for $\mathrm{C}_{35} \mathrm{H}_{70} \mathrm{O}_{6} \mathrm{Si}_{3} \mathrm{Na}[\mathrm{M}+\mathrm{Na}]^{+}$ 693.4378, found 693.4364.

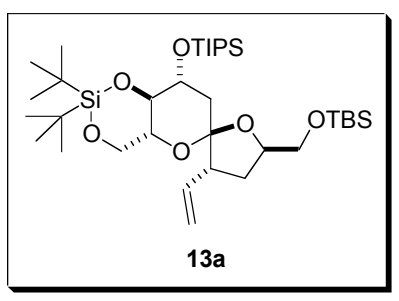

Thermodynamic spiroacetal 13a. ${ }^{1} \mathrm{H}$ NMR $\left(500 \mathrm{MHz}, \mathrm{CDCl}_{3}\right) \delta 5.91-5.82(\mathrm{~m}, 1 \mathrm{H})$, 5.21-5.09 (m, 2 H), 4.08-4.02 (m, 2 H), $4.00(\mathrm{dd}, J=9.1,5.4 \mathrm{~Hz}, 1 \mathrm{H}), 3.80-3.73(\mathrm{~m}, 4$ H), $3.53(\mathrm{dd}, J=11.1,6.6 \mathrm{~Hz}, 1 \mathrm{H}), 2.82-2.77(\mathrm{~m}, 1 \mathrm{H}), 2.17-2.11(\mathrm{~m}, 2 \mathrm{H}), 1.95(\mathrm{dd}, J$ = 10.2, $6.8 \mathrm{~Hz}, 1 \mathrm{H}), 1.85(\mathrm{dd}, J=9.8,7.2 \mathrm{~Hz}, 1 \mathrm{H}), 1.08(\mathrm{~s}, 21 \mathrm{H}), 1.03(\mathrm{~s}, 9 \mathrm{H}), 0.95(\mathrm{~s}$, $9 \mathrm{H}), 0.88$ (s, $9 \mathrm{H}), 0.05$ (s, $6 \mathrm{H}) ;{ }^{13} \mathrm{C}$ NMR $\left(125 \mathrm{MHz}, \mathrm{CDCl}_{3}\right) \delta$ 137.0, 117.1, 106.7, $79.3,78.8,71.2,70.5,67.4,67.1,54.9,43.5,34.8,29.7,27.5,27.0,26.0,22.6,20.0,18.2$, 18.1, 12.5, -5.2; HRMS (ESI) $m / z$ calcd for $\mathrm{C}_{35} \mathrm{H}_{70} \mathrm{O}_{6} \mathrm{Si}_{3} \mathrm{Na}[\mathrm{M}+\mathrm{Na}]^{+}$693.4378, found 693.4376.

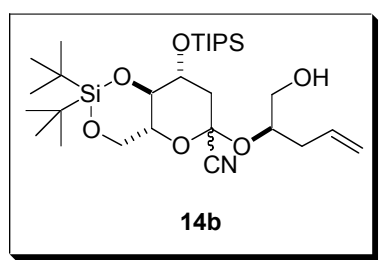


Cyano acetal 14b. The general procedure for cyano acetal formation was performed. Orthoester 14a $(0.017 \mathrm{~g}, 0.031 \mathrm{mmol}) ; \mathrm{CH}_{2} \mathrm{Cl}_{2}(0.50 \mathrm{~mL}, 0.06 \mathrm{M})$; TMSCN $(0.008 \mathrm{~mL}$, $0.081 \mathrm{mmol}) ; \mathrm{BF}_{3} \cdot \mathrm{OEt}_{2}(0.010 \mathrm{~mL}, 0.081 \mathrm{mmol})$ was added and stirred for $1.5 \mathrm{~h}$; purification by flash chromatography (10\% EtOAc/hexanes) affords $\mathbf{1 4 b}$ (colorless oil) as a 1:1 mixture of diastereomers $(0.017 \mathrm{~g}, 98 \%)$ : ${ }^{1} \mathrm{H}$ NMR $\left(500 \mathrm{MHz}, \mathrm{CDCl}_{3}\right) \delta 5.82-5.71$ (m, $1 \mathrm{H}), 5.17-5.13(\mathrm{~m}, 1 \mathrm{H}), 5.09-5.05(\mathrm{~m}, 1 \mathrm{H}), 4.19-4.13(\mathrm{~m}, 2 \mathrm{H}), 4.09-4.04$ (m, 1 H), $3.90(\mathrm{t}, J=9.7 \mathrm{~Hz}, 2 \mathrm{H}), 3.78-3.61(\mathrm{~m}, 3 \mathrm{H}), 2.45(\mathrm{dt}, J=8.8,4.8 \mathrm{~Hz}, 1 \mathrm{H}), 2.38(\mathrm{t}, J$ $=7.1 \mathrm{~Hz}, 1 \mathrm{H}), 2.30-2.26(\mathrm{~m}, 1 \mathrm{H}), 1.94-1.87(\mathrm{~m}, 1 \mathrm{H}), 1.65(\mathrm{br} \mathrm{s}, 1 \mathrm{H}), 1.10(\mathrm{~s}, 21 \mathrm{H})$, 1.05 (s, $9 \mathrm{H}), 1.00$ (s, $9 \mathrm{H}) ;{ }^{13} \mathrm{C} \mathrm{NMR}\left(125 \mathrm{MHz}, \mathrm{CDCl}_{3}\right) \delta$ 133.4, 133.2, 118.5, 118.0, $115.8,114.9,96.6,96.0,78.6,78.2(2), 71.3,70.5,70.4,69.2,66.2,66.1,63.7,44.2,43.8$, 37.7, 36.9, 27.5, 27.4, 26.9 (2), 22.7 (2), 20.0, 19.9, 18.1 (2), 12.4; IR (neat) 3433, 2941, 2893, 2865, 2359, 2336, 1109, $1069 \mathrm{~cm}^{-1}$; HRMS (ESI) $\mathrm{m} / z$ calcd for $\mathrm{C}_{29} \mathrm{H}_{55} \mathrm{NO}_{6} \mathrm{Si}_{2} \mathrm{Na}$ $[\mathrm{M}+\mathrm{Na}]^{+}$592.3466, found 592.3479.

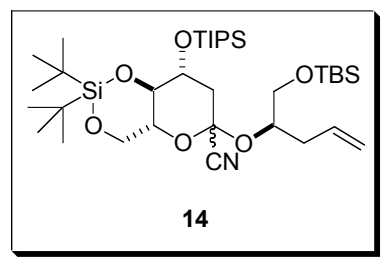

Cyano acetal 14. The general procedure for TBS ether formation of cyano acetals was performed. Cyano acetal 14b (0.017 g, $0.030 \mathrm{mmol})$; imidazole (0.023 g, $0.332 \mathrm{mmol})$; DMAP (0.009 g, $0.073 \mathrm{mmol})$; DMF (0.50 mL, $0.06 \mathrm{M})$; TBSCl (0.023 g, $0.151 \mathrm{mmol})$ was added and the reaction mixture was stirred for $21 \mathrm{~h}$; purification by flash chromatography (2\% $\mathrm{Et}_{2} \mathrm{O} /$ hexanes) affords a $1: 1$ mixture of diastereomers of $\mathbf{1 4}$ as a colorless oil $(0.020 \mathrm{~g}, 97 \%)$ : ${ }^{1} \mathrm{H} \mathrm{NMR}\left(500 \mathrm{MHz}, \mathrm{CDCl}_{3}\right) \delta 5.82-5.70(\mathrm{~m}, 1 \mathrm{H}), 5.05-$ $5.02(\mathrm{~m}, 2 \mathrm{H}), 4.17(\mathrm{~d}, J=5.9 \mathrm{~Hz}, 1 \mathrm{H}), 4.11-4.03(\mathrm{~m}, 2 \mathrm{H}), 3.89(\mathrm{t}, J=9.4 \mathrm{~Hz}, 2 \mathrm{H})$, 
3.74-3.68 (m, $2 \mathrm{H}), 3.64$ (t, $J=5.6 \mathrm{~Hz}, 1 \mathrm{H}), 2.45-2.17(\mathrm{~m}, 3 \mathrm{H}), 1.91-1.86(\mathrm{~m}, 1 \mathrm{H})$, $1.10(\mathrm{~s}, 21 \mathrm{H}), 1.05(\mathrm{~s}, 9 \mathrm{H}), 1.00(\mathrm{~s}, 9 \mathrm{H}), 0.90(\mathrm{~s}, 9 \mathrm{H}), 0.06(\mathrm{~s}, 6 \mathrm{H}) ;{ }^{13} \mathrm{C}$ NMR $(125$ $\left.\mathrm{MHz}, \mathrm{CDCl}_{3}\right) \delta 134.1,133.7,117.5,117.4,115.7,115.0,96.5,96.1,78.6,78.3,71.2(2)$, $70.6,70.5,70.4$ (2), 66.3, 66.2, 63.8, 44.3, 43.9, 39.1, 36.9, 27.5, 26.9, 25.9, 25.6, 22.7 (2), 20.0, 19.9, 18.1 (2), 12.4 (2), -5.3, -5.4; IR (neat) 2936, 2893, 2864, 2228, 1109, $1070 \mathrm{~cm}^{-1}$; HRMS (ESI) $\mathrm{m} / z$ calcd for $\mathrm{C}_{35} \mathrm{H}_{69} \mathrm{NO}_{6} \mathrm{Si}_{3} \mathrm{Na}[\mathrm{M}+\mathrm{Na}]^{+} 706.4330$, found 706.4331 .

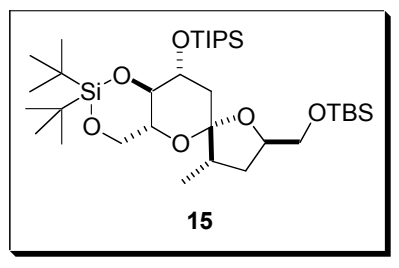

Spiroacetal 15. The general procedure for reductive decyanation alkyllithium cyclization was performed. Cyclization precursor 14 (0.026 g, $0.038 \mathrm{mmol})$; THF (0.20 $\mathrm{mL}, 0.2 \mathrm{M}$ ); solution of LiDBB (1.50 $\mathrm{mL}, 0.3 \mathrm{M}$ in THF, $0.41 \mathrm{mmol})$ was pre-cooled to $40{ }^{\circ} \mathrm{C}$; the reaction mixture was allowed to stir at $-40{ }^{\circ} \mathrm{C}$ for $1 \mathrm{~h}$; purification by flash chromatography (2\% Et $2 \mathrm{O} /$ hexanes) affords 15 as a colorless oil $(0.016 \mathrm{~g}, 81 \%):{ }^{1} \mathrm{H}$ NMR (500 MHz, $\left.\mathrm{CDCl}_{3}\right) \delta 4.13(\mathrm{dd}, J=9.7,5.1 \mathrm{~Hz}, 1 \mathrm{H}), 4.03(\mathrm{dd}, J=9.5,5.6 \mathrm{~Hz}, 1 \mathrm{H})$, $3.91(\mathrm{t}, J=10.7 \mathrm{~Hz}, 1 \mathrm{H}), 3.82-3.79(\mathrm{~m}, 1 \mathrm{H}), 3.75(\mathrm{dd}, J=10.1,6.2 \mathrm{~Hz}, 1 \mathrm{H}), 3.67(\mathrm{t}, J$ $=8.9 \mathrm{~Hz}, 1 \mathrm{H}), 3.47(\mathrm{~m}, 1 \mathrm{H}), 3.30(\mathrm{t}, J=10.0 \mathrm{~Hz}, 1 \mathrm{H}), 2.33-2.07(\mathrm{~m}, 3 \mathrm{H}), 1.87-1.83$ (m, $1 \mathrm{H}), 1.70-1.64(\mathrm{~m}, 1 \mathrm{H}), 1.08(\mathrm{~s}, 21 \mathrm{H}), 1.04(\mathrm{~s}, 9 \mathrm{H}), 0.99(\mathrm{~s}, 9 \mathrm{H}), 0.89(\mathrm{t}, J=6.2$ $\mathrm{Hz}, 1 \mathrm{H}), 0.88$ (s, $9 \mathrm{H}), 0.05$ (s, $6 \mathrm{H}) ;{ }^{13} \mathrm{C}$ NMR $\left(125 \mathrm{MHz}, \mathrm{CDCl}_{3}\right) \delta$ 107.6, 78.7, 78.0, $71.3,70.8,67.7,67.4,43.5,42.5,29.7,27.6,27.0,26.0,22.7,19.9,18.2,14.8,12.5,-5.2$ IR (neat) 2957, 2929, 2894, 2861, 1104, $1072 \mathrm{~cm}^{-1}$; HRMS (ESI) $\mathrm{m} / \mathrm{z}$ calcd for $\mathrm{C}_{34} \mathrm{H}_{70} \mathrm{O}_{6} \mathrm{Si}_{3} \mathrm{Na}[\mathrm{M}+\mathrm{Na}]^{+}$681.4378, found 681.4372. 


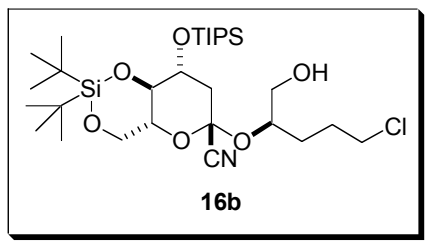

Cyano acetal 16b. To a solution of hemithioketene acetal $7(0.130 \mathrm{~g}, 0.236 \mathrm{mmol})$ in dichloromethane (2.36. $\mathrm{mL})$, was added in sequence, a solution of diol $1 \mathbf{1 0}(0.036 \mathrm{~g}, 0.260$ mmol) dissolved in $0.52 \mathrm{~mL}$ of dichloromethane and then CSA (1.2 mg, $0.0047 \mathrm{mmol})$ in one-portion. The solution was stirred at room temperature for $1 \mathrm{hr}$, concentrated under reduced pressure and the residue was purified by flash chromatography (10\% $\mathrm{Et}_{2} \mathrm{O} /$ Pentane) to afford $0.127 \mathrm{~g}$ (93\% yield) of the desired orthoester 16a (colorless oil) as a mixture of four diastereomers (four resonance signals characteristic of spiro orthoesters in the ${ }^{13} \mathrm{C}$ NMR spectrum of product were detected: 119.34 (major), 119.31 (minor), 119.11 (major), 119.08 (minor); HRMS (ESI) calcd for $\mathrm{C}_{28} \mathrm{H}_{56} \mathrm{ClO}_{6} \mathrm{Si}_{2}[\mathrm{M}+\mathrm{H}]^{+}$ 579.3305; found 565.3302. One of the minor isomers was separated by silica gel chromatography and the mixture now comprises of three diastereomers $(0.93 \mathrm{~g} 84 \%$ yield) was taken to the next step of the reaction sequence. The general procedure for cyano acetal formation was performed. Orthoester 16a $(0.019 \mathrm{~g}, 0.033 \mathrm{mmol}) ; \mathrm{CH}_{2} \mathrm{Cl}_{2}$ $(0.50 \mathrm{~mL}, 0.07 \mathrm{M}) ;$ TMSCN $(0.010 \mathrm{~mL}, 0.095 \mathrm{mmol}) ; \mathrm{BF}_{3} \cdot \mathrm{OEt}_{2}(0.012 \mathrm{~mL}, 0.095 \mathrm{mmol})$ was added and stirred for $1.0 \mathrm{~h}$; purification by flash chromatography (8\% EtOAc/hexanes) affords $\mathbf{1 6 b}$ (colorless oil) as a 10:1 mixture of 2 diastereomers (0.018 g, 88\%): ${ }^{1} \mathrm{H}$ NMR (500 MHz, $\left.\mathrm{CDCl}_{3}\right) \delta$ 4.19-4.16 (m, $\left.1 \mathrm{H}\right), 4.15-4.09$ (m, $\left.1 \mathrm{H}\right), 4.07-4.04$ (m, $1 \mathrm{H}), 3.90(\mathrm{t}, J=9.9 \mathrm{~Hz}, 1 \mathrm{H}), 3.74-3.69(\mathrm{~m}, 2 \mathrm{H}), 3.68-3.62(\mathrm{~m}, 1 \mathrm{H}), 3.60-3.57$ (m, 2 H), 2.51 (dt, $J=12.9,5.3 \mathrm{~Hz}, 1 \mathrm{H}), 2.47-2.43(\mathrm{~m}, 1 \mathrm{H}), 1.96-1.86$ (m, $2 \mathrm{H}), 1.80-1.75$ $(\mathrm{m}, 3 \mathrm{H}), 1.09(\mathrm{~s}, 21 \mathrm{H}), 1.05(\mathrm{~s}, 9 \mathrm{H}), 0.99(\mathrm{~s}, 9 \mathrm{H}) ;{ }^{13} \mathrm{C} \mathrm{NMR}\left(125 \mathrm{MHz}, \mathrm{CDCl}_{3}\right) \delta$ 
$115.2,95.9,77.9,71.4,70.4,65.9,65.0,64.1,44.7,44.3,29.3,28.2,27.4,26.9,22.7$, 19.9, 18.1, 12.4; IR (neat) 3449, 2942, 2893, 2866, 1109, $1065 \mathrm{~cm}^{-1}$; HRMS (ESI) $\mathrm{m} / \mathrm{z}$ calcd for $\mathrm{C}_{29} \mathrm{H}_{56} \mathrm{ClNO}_{6} \mathrm{Si}_{2} \mathrm{Na}[\mathrm{M}+\mathrm{Na}]^{+}$628.3232, found 628.3235 .

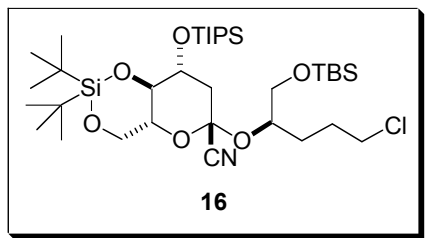

Cyano acetal 16. The general procedure for TBS ether formation of cyano acetals was performed. Cyano acetal 16b (0.018 g, $0.029 \mathrm{mmol})$; imidazole (0.016 g, $0.235 \mathrm{mmol})$; DMAP (0.004 g, $0.035 \mathrm{mmol})$; DMF (0.40 mL, $0.15 \mathrm{M})$; TBSCl (0.020 g, $0.134 \mathrm{mmol})$ was added and the reaction mixture was stirred for $19 \mathrm{~h}$; purification by flash chromatography (2\% $\mathrm{Et}_{2} \mathrm{O} /$ hexanes) affords a $10: 1$ mixture of diastereomers of $\mathbf{1 6}$ as a colorless oil (0.020 g, 97\%): ${ }^{1} \mathrm{H} \mathrm{NMR}\left(500 \mathrm{MHz}, \mathrm{CDCl}_{3}\right) \delta 4.17(\mathrm{dd}, J=11.3,5.2 \mathrm{~Hz}, 1$ H), 4.07-4.02 (m, $1 \mathrm{H}), 3.97-3.94(\mathrm{~m}, 1 \mathrm{H}), 3.89(\mathrm{t}, J=10.3 \mathrm{~Hz}, 1 \mathrm{H}), 3.74-3.72(\mathrm{~m}, 1$ H), $3.69(\mathrm{t}, J=4.4 \mathrm{~Hz}, 2 \mathrm{H}), 3.60(\mathrm{t}, J=6.0 \mathrm{~Hz}, 1 \mathrm{H}), 3.52-3.49(\mathrm{~m}, 1 \mathrm{H}), 3.44(\mathrm{dd}, J=$ 10.1, 7.7 Hz, $1 \mathrm{H}), 2.41(\mathrm{dt}, J=13.6,4.8 \mathrm{~Hz}, 1 \mathrm{H}), 1.94-1.80(\mathrm{~m}, 4 \mathrm{H}), 1.68-1.62(\mathrm{~m}, 1$ H), $1.09(\mathrm{~s}, 21 \mathrm{H}), 1.05(\mathrm{~s}, 9 \mathrm{H}), 1.00(\mathrm{~s}, 9 \mathrm{H}), 0.88(\mathrm{~s}, 9 \mathrm{H}), 0.04(\mathrm{~d}, J=12.7 \mathrm{~Hz}, 6 \mathrm{H})$; ${ }^{13} \mathrm{C}$ NMR $\left(125 \mathrm{MHz}, \mathrm{CDCl}_{3}\right) \delta$ 115.8, 95.7, 78.5, 78.1, 71.1, 70.4, 66.3, 65.2, 64.2, 45.0, $44.2,29.3,28.1,27.4,26.9,22.8,22.7,20.0,18.3,18.4,12.4,-5.4$; IR (neat) 2935, 2893, 2864, 1109, $1068 \mathrm{~cm}^{-1}$; HRMS (ESI) $\mathrm{m} / z$ calcd for $\mathrm{C}_{35} \mathrm{H}_{70} \mathrm{ClNO}_{6} \mathrm{Si}_{3} \mathrm{Na}[\mathrm{M}+\mathrm{Na}]^{+}$ 742.4097, found 742.4095 .

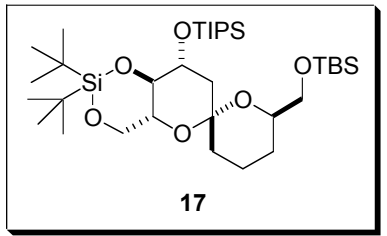


Spiroacetal 17. The general procedure for reductive decyanation alkyllithium cyclization was performed with the following modifications: A $10 \mathrm{~mL}$ round bottom flask was added the cyclization precursor $16(0.020 \mathrm{~g}, 0.027 \mathrm{mmol})$ and azeotroped with benzene $(\times 3)$. Degassed THF $(0.20 \mathrm{~mL}, 0.1 \mathrm{M})$ was added via syringe and the mixture was cooled to $-78{ }^{\circ} \mathrm{C}$. A solution of LiDBB $(0.21 \mathrm{~mL}, 0.3 \mathrm{M}$ in THF, $0.07 \mathrm{mmol})$ was added slowly down the side of the flask and the reaction mixture was allowed to stir at $78{ }^{\circ} \mathrm{C}$ for $1 \mathrm{~h}$. Purification by flash chromatography ( $2 \% \mathrm{Et}_{2} \mathrm{O} /$ hexanes) affords $\mathbf{1 7}$ as a colorless oil (0.016 g, 91\%): ${ }^{1} \mathrm{H}$ NMR $\left(500 \mathrm{MHz}, \mathrm{CDCl}_{3}\right) \delta 4.08(\mathrm{dd}, J=10.0,4.8 \mathrm{~Hz}, 1$ H), $3.92(\mathrm{t}, J=10.0 \mathrm{~Hz}, 1 \mathrm{H}), 3.90-3.87(\mathrm{~m}, 1 \mathrm{H}), 3.68(\mathrm{t}, J=9.1 \mathrm{~Hz}, 1 \mathrm{H}), 3.65(\mathrm{dd}, J=$ 10.3, $6.1 \mathrm{~Hz}, 1 \mathrm{H}), 3.56(\mathrm{dt}, J=10.3,6.2 \mathrm{~Hz}, 1 \mathrm{H}), 2.47(\mathrm{dd}, J=10.2,6.6 \mathrm{~Hz}, 1 \mathrm{H}), 3.31$ $(\mathrm{dt}, J=10.2,4.8 \mathrm{~Hz}, 1 \mathrm{H}), 2.14(\mathrm{t}, J=13.7 \mathrm{~Hz}, 1 \mathrm{H}), 2.01(\mathrm{dd}, J=13.2,5.0 \mathrm{~Hz}, 1 \mathrm{H})$, 1.72-1.58 (m, 4 H), 1.32-1.25 (m, 2 H), 1.07 (s, 21 H), 1.04 (s, 9 H), 0.98 (s, 9 H), 0.88 (s, $9 \mathrm{H}), 0.04(\mathrm{~s}, 6 \mathrm{H}) ;{ }^{13} \mathrm{C} \mathrm{NMR}\left(125 \mathrm{MHz}, \mathrm{CDCl}_{3}\right) \delta$ 98.0, 80.0, 71.3, 70.9, 69.8, 67.5, 66.6, 45.6, 29.7, 29.1, 27.6, 27.0, 26.9, 25.8, 22.7, 19.9, 18.4, 18.2, 12.5, -5.2; IR (neat) 2935, 2891, 2864, 1106, $1074 \mathrm{~cm}^{-1}$; HRMS (ESI) $m / z$ calcd for $\mathrm{C}_{34} \mathrm{H}_{70} \mathrm{O}_{6} \mathrm{Si}_{3} \mathrm{Na}[\mathrm{M}+\mathrm{Na}]^{+}$ 681.4378, found 681.4357 .

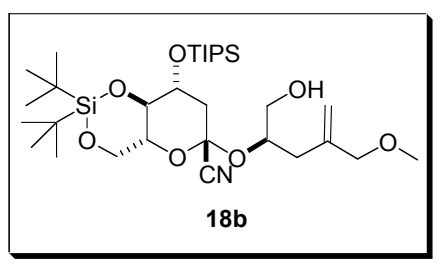

Cyano acetal 18b. The general procedure for cyano acetal formation was performed. Orthoester 18a $(0.034 \mathrm{~g}, 0.057 \mathrm{mmol}) ; \mathrm{CH}_{2} \mathrm{Cl}_{2}(0.50 \mathrm{~mL}, 0.11 \mathrm{M})$; TMSCN $(0.024 \mathrm{~mL}$, $0.228 \mathrm{mmol}) ; \mathrm{BF}_{3} \cdot \mathrm{OEt}_{2}(0.043 \mathrm{~mL}, 0.342 \mathrm{mmol})$ was added and stirred for $1.0 \mathrm{~h}$; purification by flash chromatography (20\% EtOAc/hexanes) affords $\mathbf{1 8 b}$ (colorless oil) as 
a 10:1 mixture of diastereomers $(0.029 \mathrm{~g}, 84 \%):{ }^{1} \mathrm{H} \mathrm{NMR}\left(500 \mathrm{MHz}, \mathrm{CDCl}_{3}\right) \delta 5.17(\mathrm{~s}, 1$ H), $5.03(\mathrm{~s}, 1 \mathrm{H}), 4.26-4.23(\mathrm{~m}, 1 \mathrm{H}), 4.18(\mathrm{dd}, J=11.2,4.6 \mathrm{~Hz}, 1 \mathrm{H}), 4.08-4.03(\mathrm{~m}, 1$ H), 3.92-3.87 (m, $3 \mathrm{H}), 3.72(\mathrm{t}, J=4.8 \mathrm{~Hz}, 2 \mathrm{H}), 3.65(\mathrm{dd}, J=12.2,3.0 \mathrm{~Hz}, 1 \mathrm{H}), 3.52$ (dd, $J=12.2,5.8 \mathrm{~Hz}, 1 \mathrm{H}), 3.34(\mathrm{~s}, 3 \mathrm{H}), 2.45-2.36(\mathrm{~m}, 3 \mathrm{H}), 1.93(\mathrm{dd}, J=13.7,11.5 \mathrm{~Hz}$, $1 \mathrm{H}), 1.10(\mathrm{~s}, 21 \mathrm{H}), 1.05(\mathrm{~s}, 9 \mathrm{H}), 0.99(\mathrm{~s}, 9 \mathrm{H}) ;{ }^{13} \mathrm{C} \mathrm{NMR}\left(125 \mathrm{MHz}, \mathrm{CDCl}_{3}\right) \delta 141.2$, $116.1,115.0,95.7,79.5,78.0,75.8,71.3,70.4,66.0,64.4,58.1,44.2,35.2,27.4,26.9$, 22.7, 20.0, 19.9, 18.1, 12.4; IR (neat) 3452, 2942, 2893, 2866, 1109, $1068 \mathrm{~cm}^{-1}$; HRMS (ESI) $m / z$ calcd for $\mathrm{C}_{31} \mathrm{H}_{59} \mathrm{NO}_{7} \mathrm{Si}_{2} \mathrm{Na}[\mathrm{M}+\mathrm{Na}]^{+} 636.3728$, found 636.3704 .

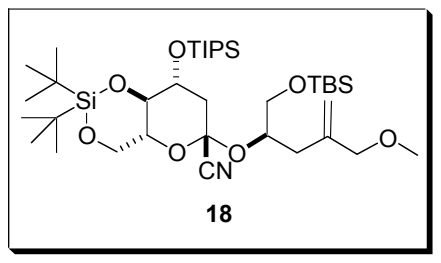

Cyano acetal 18. The general procedure for TBS ether formation of cyano acetals was performed. Cyano acetal 18b (0.026 g, $0.042 \mathrm{mmol})$; imidazole (0.023 g, $0.343 \mathrm{mmol})$; DMAP (0.002 g, $0.017 \mathrm{mmol})$; DMF (0.50 mL, $0.08 \mathrm{M})$; TBSCl (0.021 g, $0.140 \mathrm{mmol})$ was added and the reaction mixture was stirred for $20 \mathrm{~h}$; purification by flash chromatography (5\% $\mathrm{Et}_{2} \mathrm{O} /$ hexanes) affords a $10: 1$ mixture of diastereomers of $\mathbf{1 8}$ as a colorless oil (0.029 g, 96\%): ${ }^{1} \mathrm{H}$ NMR (500 MHz, $\left.\mathrm{CDCl}_{3}\right) \delta 5.16(\mathrm{~s}, 1 \mathrm{H}), 5.04(\mathrm{~s}, 1 \mathrm{H})$, $4.16(\mathrm{dd}, J=10.7,4.4 \mathrm{~Hz}, 1 \mathrm{H}), 4.10-3.97$ (m, $2 \mathrm{H}), 3.94-3.87$ (m, $3 \mathrm{H}), 3.72-3.66$ (m, 3 H), $3.50(\mathrm{dd}, J=10.4,6.5 \mathrm{~Hz}, 1 \mathrm{H}), 3.33(\mathrm{~s}, 3 \mathrm{H}), 2.56(\mathrm{dd}, J=14.1,5.5 \mathrm{~Hz}, 1 \mathrm{H}), 2.37$ $(\mathrm{dd}, J=13.6,4.9 \mathrm{~Hz}, 1 \mathrm{H}), 2.27(\mathrm{dd}, J=14.1,7.0 \mathrm{~Hz}, 1 \mathrm{H}), 1.85(\mathrm{dd}, J=13.6,11.5 \mathrm{~Hz}, 1$ H), $1.10(\mathrm{~s}, 21 \mathrm{H}), 1.05$ (s, $9 \mathrm{H}), 1.00(\mathrm{~s}, 9 \mathrm{H}), 0.89$ (s, $9 \mathrm{H}), 0.03$ (s, $6 \mathrm{H}) ;{ }^{13} \mathrm{C} \mathrm{NMR}(125$ $\left.\mathrm{MHz}, \mathrm{CDCl}_{3}\right) \delta 141.6,115.5,115.2,96.5,78.2$ (2), 75.6, 71.1, 70.4, 66.3, 64.8, 58.1, $44.2,35.1,27.5,26.9,25.9,22.7,20.0,18.3,18.1,12.4,-5.3$; IR (neat) 2935, 2893, 2864, 
1109, $1070 \mathrm{~cm}^{-1}$; HRMS (ESI) $\mathrm{m} / z$ calcd for $\mathrm{C}_{37} \mathrm{H}_{73} \mathrm{NO}_{7} \mathrm{Si}_{3} \mathrm{Na}[\mathrm{M}+\mathrm{Na}]^{+} 750.4593$, found 750.4583 .

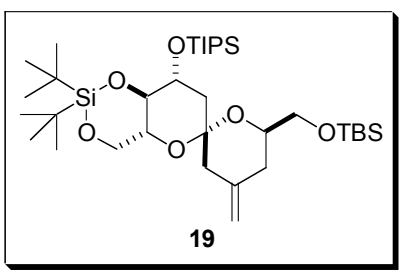

Spiroacetal 19. The general procedure for reductive decyanation alkyllithium cyclization was performed. Cyclization precursor 18 (0.016 g, $0.021 \mathrm{mmol})$; THF (0.20 $\mathrm{mL}, 0.1 \mathrm{M})$; solution of LiDBB (1.20 mL, 0.4 M in THF, $0.45 \mathrm{mmol})$ was pre-cooled to $40{ }^{\circ} \mathrm{C}$; the reaction mixture was allowed to stir at $-40{ }^{\circ} \mathrm{C}$ for $1 \mathrm{~h}$; purification by flash chromatography $\left(5 \% \mathrm{CH}_{2} \mathrm{Cl}_{2} /\right.$ hexanes $-2 \% \mathrm{Et}_{2} \mathrm{O} /$ hexanes $)$ affords 19 as a colorless oil (0.008 g, 71\%): ${ }^{1} \mathrm{H}$ NMR (500 MHz, $\left.\mathrm{CDCl}_{3}\right) \delta 4.80-4.72(\mathrm{~m}, 1 \mathrm{H}), 4.54(\mathrm{~d}, J=7.8 \mathrm{~Hz}, 1$ H), 4.14-4.10 (m, $1 \mathrm{H}), 3.91(\mathrm{t}, J=9.0 \mathrm{~Hz}, 1 \mathrm{H}), 3.82-3.63(\mathrm{~m}, 4 \mathrm{H}), 3.48-3.41(\mathrm{~m}, 1 \mathrm{H})$, $3.27(\mathrm{dd}, J=10.2,6.3 \mathrm{~Hz}, 1 \mathrm{H}), 2.38(\mathrm{dd}, J=10.1,6.5 \mathrm{~Hz}, 1 \mathrm{H}), 2.16-2.07(\mathrm{~m}, 1 \mathrm{H})$, 1.71-1.48 (m, $4 \mathrm{H}), 1.08$ (s, $21 \mathrm{H}), 1.04$ (s, $9 \mathrm{H}), 0.98$ (s, $9 \mathrm{H}), 0.89$ (s, $9 \mathrm{H}), 0.04$ (s, 6 $\mathrm{H}) ;{ }^{13} \mathrm{C} \mathrm{NMR}\left(125 \mathrm{MHz}, \mathrm{CDCl}_{3}\right) \delta 148.7,112.8,100.3,79.3,79.0,72.3,70.9,70.1,66.8$, $45.6,43.1,40.3,27.5,27.0,25.9,22.7,19.9,18.1,12.5,-5.3$; IR (neat) 2930, 2893, 2860, 1104, $1075 \mathrm{~cm}^{-1}$; HRMS (ESI) $m / z$ calcd for $\mathrm{C}_{35} \mathrm{H}_{72} \mathrm{O}_{6} \mathrm{Si}_{3} \mathrm{Na}[\mathrm{M}+2 \mathrm{H}+\mathrm{Na}]^{+} 695.4534$, found 695.4510 . 
nOe signals for various spiroacetals:
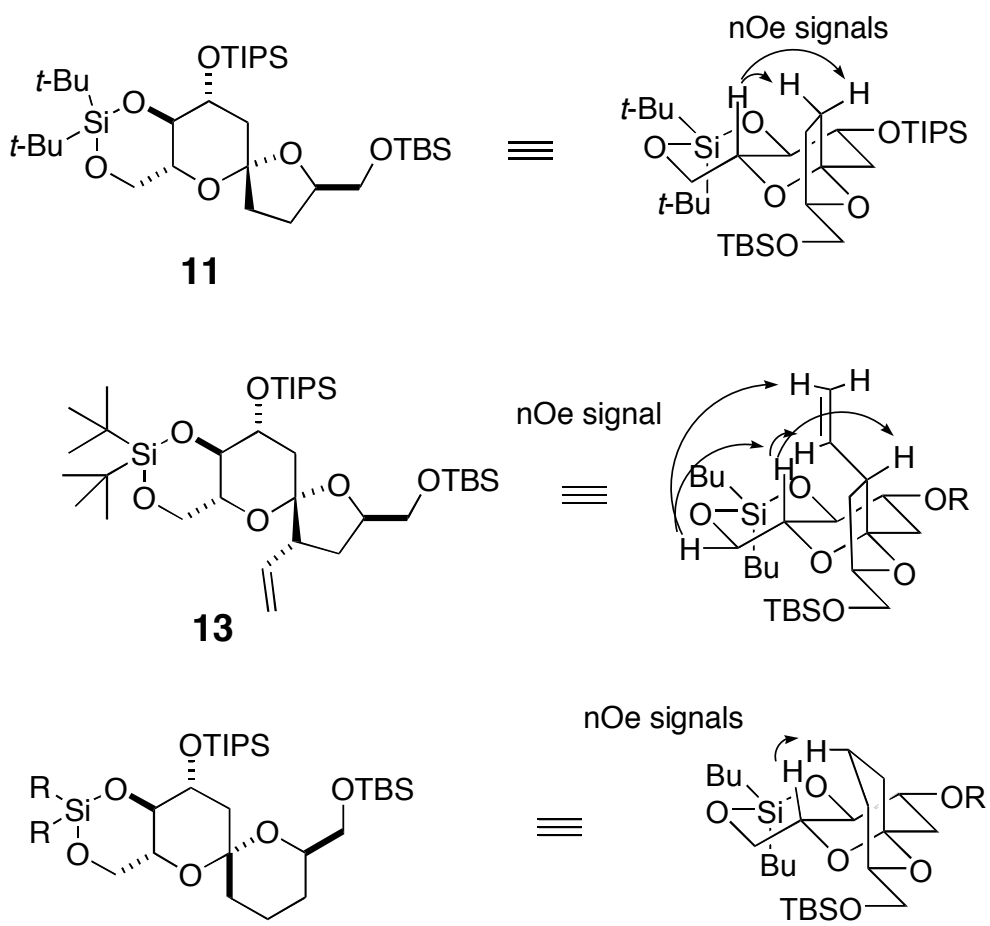

17

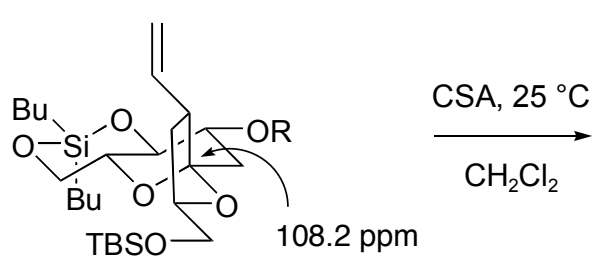

13

contra-thermodynamic
nOe signals

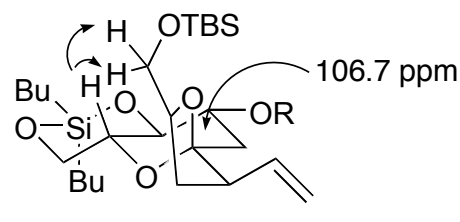

thermodynamic 